\title{
La tía fingida («y la dueña más fingida todavía») de Antonio del Real $(1983)^{*}$ \\ La tía fingida («and the More Pretended Maid») by Antonio del Real (1983)
}

\section{Victoria Aranda Arribas}

https://orcid.org/0000-0003-2913-3918

Universidad de Córdoba

ESPAÑA

I22ararv@uco.es

[Hipogrifo, (issn: 2328-1308), 8.2, 2020, pp. 433-472]

Recibido: 28-04-2020 / Aceptado: 12-05-2020

DOI: http://dx.doi.org/10.13035/H.2020.08.02.27

Resumen. El presente artículo analiza La tía fingida (Antonio del Real, 1983), primer capítulo de los seis que compusieron la serie Las pícaras, producida por José Frade para Televisión Española. Libre adaptación de la novelita descubierta en 1788 y atribuida a Miguel de Cervantes, se arroja luz aquí sobre las diferencias entre el telefilme y el relato del Siglo de Oro, fruto, las más de las veces, del cambio de contexto histórico-social.

Palabras clave. La tía fingida; Cervantes; Las pícaras; Antonio del Real; Televisión Española; adaptación televisiva.

Abstract. This article analyzes La tía fingida (Antonio del Real, 1983), first episode of six filmed for the TV show Las pícaras produced by José Frade for Televisión Española. Free adaptation of the homonymous short-novel discovered in 1788 and attributed to Miguel de Cervantes, this paper will cast light on the many differences between this film and the Golden Age tale, most of them derived from the socio-historical context change.

Keywords. La tía fingida; Cervantes; Las pícaras; Antonio del Real; Televisión Española; TV Adaptation.

* Este artículo se inscribe en el marco del Proyecto de Excelencia I+D+i del MINECO La novela corta del siglo XVII: estudio y edición (y III) (FFI2017-85417-P) y ve la luz gracias a la financiación de una Beca FPU concedida por el MECD. 


\section{1. «¿QUIÉN ES EL PADRE?»: LA IMPORTANCIA DE LLAMARSE CERVANTES}

Cuando en 1788 el ilustrado Isidoro Bosarte descubrió el manuscrito Porras de la Cámara en la Biblioteca de los Reales Estudios de San Isidro', el destino dictó sobre La tía fingida una doble sentencia. A partir de ese momento, el mundo sabría de la existencia de una curiosa novela, ignorada hasta entonces. Pero la fama siempre tiene un precio: desde su aparición se ha reparado casi exclusivamente en su polémica autoría, y bastante menos en el propio texto. En efecto, si formó parte del corpus de adaptaciones realizadas para la serie Las pícaras (TVE, 1983), la causa hay que buscarla en la discutida paternidad cervantina.

Ha llovido lo suyo desde los acalorados debates entre aquellos que desmintieron que hubiera salido de la pluma del alcalaíno y quienes lo afirmaron a capa y espada. Así, el citado Bosarte no tardaría en comunicar a sus colegas bibliotecarios su intuición acerca del inventor de este relato. De hecho, pretendía publicar un estudio en el que lo cotejaba con el resto de las obras de Cervantes. Y cuando surgió alguna voz que cuestionaba su teoría, fue enseguida atajada, ya en los albores del Ochocientos, por eruditos de la talla de García Arrieta (1814, p. XXVII) o Gallardo (1835, pp. 9-10). Aunque no todos pondrían la mano en el fuego. Andrés Bello, que nunca llegó a escribir nada oficial al respecto,

en carta a un [sabio] español decía que no acababa de persuadirse de que fuera obra de [Cervantes]. Don Miguel Luis de Amusátegui, en la Vida de Bello (Santiago de Chile, 1882), refiere que oyó hablar a Bello en varias ocasiones sobre esto, el cual se inclinaba a opinar que La tía fingida [la escribió el mismo] que el Quijote de Avellaneda, atendiendo a ciertas expresiones peculiares que son comunes a una y otra obra (Castro, 1889, pp. 184-185).

El alcalde (y falsario) gaditano Adolfo de Castro, encargado de revivir aquella anécdota, anotaría un puñado de estilemas, los cuales, supuestamente, le había referido el polígrafo de Caracas. Foulché-Delbosc (1899), más cauto, concluyó que, mientras no se exhumaran nuevas pruebas, la cuestión quedaba en suspenso. Y a su zaga, Bonilla (1911, p. 6) arguyó que «juzgar la paternidad de un libro por analogías de estilo es siempre faena arriesgada [...]. Sin embargo, [...] habiendo de determinarse sin excusa entre afirmar que La tía fingida es de Cervantes o negarlo sin rodeos ni callejuelas, [confiesa] que optaría por lo primero». La plana se la enmendaría el respetadísimo Menéndez Pelayo (1915/2008, p. 439), para quien las deudas de Claudia con la Celestina -y volveré sobre este asunto- resultaban tan excesivas que contradecían el estilo de Cervantes.

Al margen de sus tiras y aflojas, tan ilustres avalistas e impugnadores -excepción hecha de don Marcelino - tuvieron una cosa en común: todos subrayaban los méritos de la novela, cuando la suponían cervantina, o bien la denostaban sin ambages, caso de opinar lo contrario. Por otra parte, tampoco se olvide que entonces

1. Para profundizar en la transmisión de La tía fingida, ver Lucía Megías, 2018. 
los argumentos, en un sentido u otro, acostumbraban a basarse en corazonadas que Icaza (1916, p. 68) denominó «aire de familia»².

Apráiz iría bastante más lejos, resuelto como estaba a emprender aquella tarea que Bosarte dejara pendiente: en su concienzudo artículo de principios del siglo pasado incluyó un «diccionario cervantino» en el que pasaba revista a cada una de las frases de este relato, alumbrando sus analogías con otros libros del alcalaíno. Por último, sumó un apéndice en el que vinculaba los personajes y motivos de La tía fingida con varias de las Novelas ejemplares (1613) y el Quijote (1605-1615).

Sus desvelos tendrían oportuna respuesta crítica, aunque una década más tarde, gracias al mexicano Francisco de Icaza (1916). Si Apráiz se había afanado en sistematizar las coincidencias léxicas y fraseológicas de La tía fingida con otros libros del complutense, Icaza (1916, pp. 168-169) opuso ejemplos idénticos en el haber de otros ingenios. Ya en la segunda mitad de la última centuria, Criado de Val (1953) seguiría la estela del historiador azteca y de nuevo refutó la atribución cervantina -y de paso la del ladino Avellaneda-, arbitrando que era Porras de la Cámara en persona quien estaba detrás de La tía fingida.

Con todo, el principal duelo a lo largo de esta brumosa guerra, que dura ya más de doscientos años, la sostuvieron los hispanistas sajones Edward Aylward y Geoffrey Stagg. El primero no solo le negó el pan y la sal a La tía fingida, sino también a sus compañeras del códice Porras: Rinconete y Cortadillo y El celoso extremeño (Aylward, 1982, p. 28). Stagg saldría a la arena con un minucioso artículoreseña que hacía hincapié en la falta de rigor de su colega: «There is an admirable principle of justice: that a man is to be presumed innocent until he is proved guilty. Aylward has decided that Cervantes is guilty (of plagiarism) before the trial has begun» (1984, p. 142). Y para echar más leña al fuego, incluso aventuró los dos estemas de Rinconete y Cortadillo y El celoso extremeño, rubricando que «the texts of the two stories in the Porras MS. are revisions of originals written earlier by Cervantes and printed by Cuesta in 1613» (Stagg, 1984, p. 153). Eso sí, por la historia de Claudia y Esperanza pasó algo más que de puntillas ${ }^{3}$.

Ya en nuestro siglo, Madrigal (2003) e Isla García (2010) han ensanchado los pasos de Apráiz a la hora de buscar parecidos entre La tía fingida y la prosa de Cervantes. Y en fechas muy recientes, Rodríguez López-Vázquez (2013 y 2018) acudió a la estilometría y a un aparato matemático anclado a matrices lineales, logaritmos y ecuaciones basadas en el número e que aplicó sobre el códice Porras y el de la Colombina. Todo esto para asegurar que existe un $95 \%$ de posibilidades de que el Manco de Lepanto sea el autor de la novela (2013, p. 69).

Por último, Sáez la editó en 2018 a nombre de Miguel de Cervantes; sin orillar que había figurado como apéndice en las Novelas ejemplares editadas por García López (2013) para la «Biblioteca Clásica» de la Real Academia Española, bajo la dirección de Francisco Rico, que, como quien no quiere la cosa, resolvió que La tía fingida es de Cervantes «y no se hable más» (Demicheli, 2005, s. p.).

2. Ver asimismo Apráiz, 1906, p. 20.

3. Aylward (1994, pp. 109-115) contrarreplicaría en otro artículo sin demasiada solidez. 
En su introducción, Sáez (2018, pp. 16-17) cifraba las claves del rechazo cervantino en: a) su moralidad ambigua; b) su mediana categoría; y c) el exilio de La tía fingida del conjunto de las Ejemplares ${ }^{4}$. Tales prejuicios se vincularon además con

una determinada imagen heroica de Cervantes, positiva a más no poder, por la que un sector de la crítica ha convertido [su] biografía en una suerte de hagiografía [...] y para [el] que todo el escándalo biográfico (como la huida a Italia) o creativo (como La tía fingida) era un verdadero sacrilegio. La idea de que [el complutense] no podía emplear su ingenio en un divertimento desenfadado -o desvergonzado- no pasa de ser un prejuicio crítico, totalmente contrario a los autorretratos cervantinos, en los que gusta de dibujarse como un ingenio cómico (2018, p. 17).

Por fortuna, la tormenta parece haber amainado durante los dos últimos lustros: asistimos hoy a la juiciosa superación de ese perfil divinizado de Cervantes; con vistas a consentir que el autor del Quijote también pudo escribir una nonada. Porque, la verdad sea dicha, La tía fingida no es precisamente memorable. He aquí su mayor problema a la hora de pagarse de tan ilustre denominación de origen. Ahora bien, tampoco todas las Novelas ejemplares, ya se trate de hermanas biológicas o adoptivas de la que nos ocupa, son como para tirar cohetes. Así lo estimó Javier Marías (2013, pp. 55-56), que encontraba algunas de ellas «decepcionantes y consabidas»:

En alguna ocasión he dicho que el peor novelista actual es, en cierto sentido, superior a Cervantes, por la sencilla razón de que este no contaba con Cervantes para su aprendizaje; y cualquiera de los que escribimos hoy [...] hemos aprovechado sus enseñanzas, sus innovaciones, sus recursos, en mayor o menor grado. Lo curioso es que con el Quijote no se produce [...] esa sensación de déjà vu, de previsibilidad, de convención conocida, que lo invade a uno en las Novelas más estrictamente narrativas, o más de enredo y peripecia, o más de argumento, como prefiera decirse. Y acaba uno teniendo la impresión de que lo que mejor se le daba a Cervantes era lo que aún hoy muchos juzgan lo más «impropio» de las novelas y cuentos, o incluso - palabra muy querida por los críticos más anticuados - lo más «impertinente» a la historia contada. Es decir: la digresión, el brujuleo, el hilo roto o suelto, el inciso, el excurso, la reflexión ocasional - puesta en boca del narrador o de algún personaje-, lo que en teatro se llamaría el «aparte», la situación o circunstancia arbitraria o inexplicable, la errabundia, el salto de un asunto a otro, incluso el abandono caprichoso de una línea argumental que parecería exigir su continuación y su clausura, su «redondez» y su término, para satisfacción de los lectores que sólo desean saber qué pasó y cómo acabó todo, de los más convencionales.

4. Pese a su no inclusión en el volumen de 1613, quizá funcione como una pista interna de la ascendencia de La tía fingida el uso del sintagma «entretenimiento y ejercicios»: «Informose del paje la astuta Claudia de la calidad y condiciones de señor de su renta, de su inclinación y de sus entretenimientos y ejercicios» (Cervantes, La tía fingida, p. 635). Recuérdese que Cervantes emplea una ditología muy semejante en su «Prólogo» a las Ejemplares: «Mi intento ha sido poner en la plaza de nuestra república una mesa de trucos, donde cada uno pueda llegar a entretenerse sin daño de barras; digo, sin daño del alma ni del cuerpo, porque los ejercicios honestos y agradables antes aprovechan que dañan» (Cervantes, Prólogo a las «Novelas ejemplares», p. 18). Las cursivas son mías. 
De ahí, quizá, la escasa bibliografía sobre una peripecia tan poco «redonda» y «digresiva» como es la de doña Claudia y Esperanza. Los trabajos que han dejado atrás el misterio de la atribución abundan en el retrato de la vida prostibularia (Rodríguez-Luis, 1980; Márquez Villanueva, 1990; Hsu, 2005; Isla García, 2010; López Rubio, 2016): el segundo de los motivos - complementario, sin duda, del linaje cervantino- que convirtió a La tía fingida en un texto idóneo para formar parte de Las pícaras 5 .

\section{LA TíA FINGIDA O EL REGRESO DE LA PUTA VIEJA CELESTINA}

La miniserie Las pícaras fue producida por José Frade para Radio Televisión Española y se emitió en la primera cadena desde el 8 de abril al 13 de mayo de 1983. Compuesta por seis capítulos independientes que tenían como objetivo y común denominador presentar la picaresca femenina de forma atractiva al público de la Transición, La tía fingida, dirigida por Antonio del Real (Jaén, 1947), se encargó de abrir este ciclo. Las obras que inspiraron el resto de episodios serían (por orden de programación):

1. La garduña de Sevilla (1642) de Alonso de Castillo Solórzano: dirigida por Paco Lara Polop y con la malograda Amparo Muñoz como Rufina.

2. La viuda valenciana (c. 1595-1600) de Lope de Vega: filmada por Paco Regueiro, en esta oportunidad fue Cristina Marsillach quien dio vida a Leonarda ${ }^{6}$.

5. Reduzco a una larga nota, que sin embargo considero de valor, el debate sobre la fecha de redacción, casi tan encendido como el de la autoría - tan traída y tan llevada-. En su biografía de Cervantes, Márquez Villanueva (1992, pp. 124-125) la dató antes del 1609-1611, ya que opinaba que debió escribirse antes que La española inglesa. Su conjetura se basa en la frase «tal fuerza tiene la discreción y hermosura» (Cervantes, La tía fingida, p. 649) del final del relato, pues se lee una parecida en la cuarta de las Ejemplares: «cuánto puede la virtud y cuánto la hermosura» (Cervantes, La española inglesa, p. 263). Con un horizonte más sobrio y general, García López (2015, p. 156) postuló que «no se trata, por supuesto, de una relación de causa y efecto, pero si analizamos con cuidado el estilo de vida que lleva Cervantes en los años de 1587-1600, tenemos la sensación de que escribir relatos cortos era lo más llevadero. Sáez (2018, pp. 22-23) la considera «una novelita de mocedad [...] [que] puede datarse [...] posiblemente hacia 1605». En suma, ningún crítico ha aducido datos concluyentes. Por mi parte, arriesgo que la descripción de doña Claudia en La tía fingida le debe mucho a «Diez años vivió Belerma» (1582), romance carolingio en clave burlesca -y de veras salaz- que Góngora dedicó a las viudas de Roldán y Durandarte. Personajes, por cierto, junto al viejo Montesinos, que resucitarían en el episodio de la cueva de Montesinos del Quijote (II, XXII). Si Belerma vestía «tocas de anjeo crudo» (v. 45), «monjilón de bayeta» (v. 46) y un «manto basto, peludo» (v. 47), Claudia irá ataviada aquí con «tocas blancas como la nieve, más largas que la sobrepelliz de un canónigo portugués, plegadas sobre la frente», «un manto de seda y lana» $\mathrm{y}$ «con un gran rosario al cuello de cuentas sonadoras, tan gordas como las de Santenuflo, que a la cintura la llegaba» (Cervantes, La tía fingida, p. 625). Repárese sobre todo en este último detalle, dado que doña Alda perdió a su marido «el día de Santiñuflo» (v. 58) (Góngora, Romances, 1998, pp. 255-267). Este manojo de simetrías invitan a proponer el año de 1582, y no antes, como fecha post quem para La tía fingida. Agradezco esta glosa a Rafael Bonilla Cerezo (Universidad de Córdoba).

6. TVE ha adaptado esta pieza otro par de veces: la primera, en 1975, para El teatro, con María del Puy y Fernando Guillén como protagonistas; y, la más reciente, en 2010, dirigida por Carlos Sedes e interpretada por Aitana Sánchez-Gijón y Fran Perea, en una reinvención del mítico Estudio 7. Ví- 
3. La pícara Justina (1605) de Francisco López de Úbeda: bajo la supervisión de José María Gutiérrez, el papel protagonista recayó sobre Ana García Obregón.

4. La lozana andaluza (1528) de Francisco Delicado: rodada por Chumy Chúmez, el reto de encarnar a Aldonza lo asumiría Norma Duval.

5. La hija de Celestina (1612) de Alonso Jerónimo de Salas Barbadillo: tras la cámara se puso Angelino Fons, mientras que Victoria Vera encarnó a la ingeniosa Elena.

Puede que sorprenda la inclusión de una novela como La tía fingida en una teleserie que aspiraba a divulgar la picaresca. Sin embargo, conviene incidir en la afinidad de este relato con tres de las herederas del Lazarillo (1554), la obra que dio carta de naturaleza a este género, toda vez que los enredos de doña Claudia y Esperanza discurren a caballo entre lo celestinesco y la picaresca femenina ${ }^{7}$. Recuerdo que ya en la misma portada de La lozana andaluza - la segunda entre las de su clase- se mostraba el vínculo con la tragicomedia de Rojas (Fig. 1). De igual modo que la de La pícara Justina, que pasa por ser la fundadora de la otra tradición - la de la rufianería mujeril-, confesaba a las claras sus deudas con La Celestina (1499) y el Guzmán de Alfarache (1599-1604) de Mateo Alemán: es por ello que en la xilografía, la protagonista de López de Úbeda, flanqueada por este par de maleantes de nuestras letras, navega a bordo de la barca de Caronte (Fig. 2) ${ }^{8}$. Y tampoco se descuide que el sexto capítulo de Las pícaras - no creo que se trate de

deo disponible en línea: <https://www.rtve.es/alacarta/videos/estudio-1/estudio-1-viuda-valenciana-20101228-2206-169/975755/> (consultado el 21/04/2020).

7. Como explicara Arredondo (1993, p. 11), «las protagonistas de La Pícara Justina, La Ingeniosa Elena, Teresa de Manzanares y La Garduña de Sevilla constituyen un cuarteto femenino tan interesante como controvertido en la historia literaria. El nexo de unión entre ellas abarca unos cuarenta años (desde 1605 a 1642), decisivos para la historia de la narrativa del Siglo de Oro; en ese lapso de tiempo evoluciona la picaresca, triunfa la narrativa corta y ambas formas se entremezclan para dar lugar a libros misceláneos de dudosa y difícil clasificación». Ver asimismo Rey Hazas (2003, p. 354) y Rodríguez Mansilla (2012, p. 39). Por otra parte, cabe precisar que, frente a las tradicionales heroínas, idealizadas y perfectas, la pícara «solo puede paragonarse con antiheroínas como Celestina o Lozana» (Arredondo, 1993, p. 12); de ahí que tampoco extrañe la horma de la que salió doña Claudia. Sin embargo, estoy muy de acuerdo con Ruffinatto en que «el prototipo de la "mujer libre", lejos de materializarse en la figura de Celestina, se encuentra precisamente en los personajes secundarios del Lazarillo y, principalmente, en la barragana del Arcipreste, que no por casualidad reivindica su libertad de acción y su derecho a salir y entrar en la casa de su amancebado cuando se le antoje sin que su marido (Lázaro) se atreva a reprocharle nada» (2019, p. 77). Por consiguiente, La tía fingida de ningún modo debe clasificarse como una novela picaresca, pero sí que presenta personajes de veras apicarados. Y si doña Claudia le rinde tributo a la alcahueta de Rojas, Esperanza formará parte de esa otra estirpe a la que aludió Ruffinato, perfilada en las obras de López de Úbeda, Salas Barbadillo y Castillo Solórzano.

8. Respecto a dicho grabado, Ruffinatto (2019, pp. 76-77) observó que «el primer responsable de la vida picaresca (Lazarillo) no está con los otros en la cubierta de la nave sino que viaja solo y remando en un bote que remolca la misma nave. [...] Este apartamiento de Lázaro de los demás personajes picarescos si, por un lado, nos sugiere su exclusión de la categoría propiamente dicha (como bien sabemos, Lázaro no es exactamente un pícaro), por otro lado, a pesar de esta exclusión y mediante la función "remolcadora" que la historia de Lázaro ejerce con respecto a la vida de los pícaros propiamente dichos, nos informa sobre la intensidad del diálogo intertextual entre La vida de Lazarillo de Tormes y las vidas del pícaro Guzmán de Alfarache y de la pícara Justina». 
ningún azar - se le dedicó a Elena, otra famosa señora de la bribia. Conocida como La hija de Celestina, lucía siempre «tan sutil de ingenio que era su corazón la recámara de la mentira, donde hallaba siempre el [...] traje más a su propósito» (Salas Barbadillo, La hija de Celestina, p. 84).

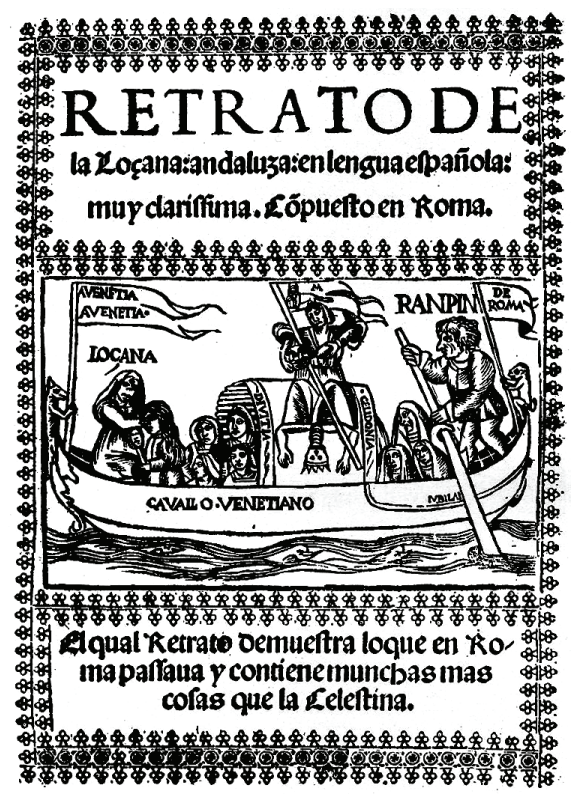

Figura 1

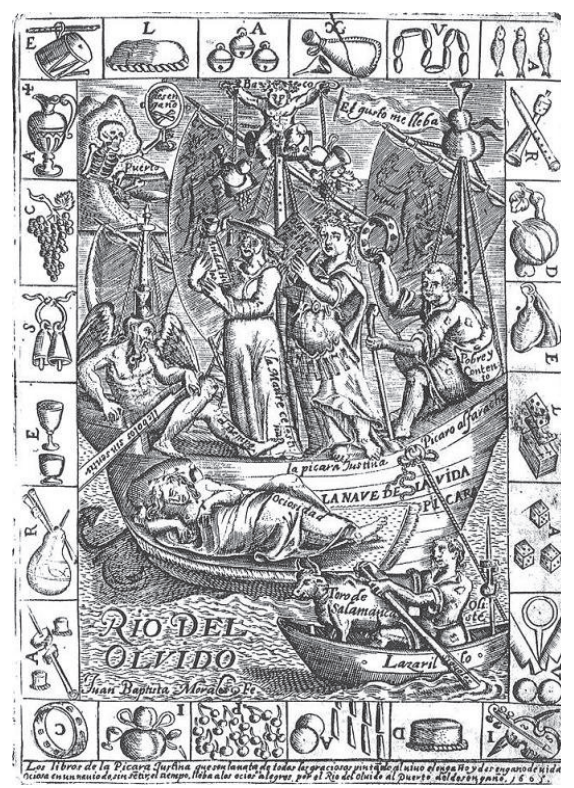

Figura 2 
Caso de que fuera el autor de La tía fingida, reparemos en cómo Cervantes persiguió aquí una alianza entre ambos géneros ${ }^{9}$. Y repito que no debe asombrarnos, pues disponemos de un ramillete de textos -tampoco muchísimos- del Barroco que entroncan La Celestina con la dinastía del Lazarillo y el Guzmán ${ }^{10}$, o bien con la novela corta: El rufián dichoso (1615) de Cervantes, la Escuela de Celestina y el hidalgo presumido (1620) de Salas Barbadillo, La constante cordobesa (1626) de Céspedes y Meneses, El estudiante confuso (1641) de Sanz del Castillo y El siglo pitagórico y vida de don Gregorio Guadaña (1644) de Enríquez Gómez ${ }^{11}$. En nuestros días, la agudeza de Martín de Riquer lo llevó a editar de forma conjunta La Celestina y Lazarillos (Vergara, 1963). Y siquiera de pasada, valdrá la pena citar el acusado protagonismo que García Jambrina otorgó a los dos personajes en El manuscrito de piedra (2008) y El manuscrito de nieve (2010)12.

En La tía fingida, dicho hibridismo toma cuerpo en Esperanza, joven ramera a la caza del medro social -como la Elena de Salas Barbadillo-, y también en doña Claudia, la vieja alcahueta que por un trentín -igual que Celestina- sería capaz de vender su alma al mismísimo diablo. Esta última, además, revela «sus puntas y

9. Más allá de la cuestión genérica, Jiménez Patón, en la segunda edición de su Elocuencia española en arte (1621), incluida en el Mercurius Trimegistus, escribió acerca de los estilos: «El tenue género de lo que se dice es el de las conversaciones, hablas familiares de corrillos, juntas, lenguaje claro y común (como lo difine Cicerón en los Oficios) y a este se reducen los librillos de entretenimiento y donaire como el de Carnestolendas, Lazarillo de Tormes, Celestina, etcétera» (Madroñal Durán, 2009, p. 299). Núñez Rivera (2017) ha explicado cómo «en 1606 un viajero quizás alemán anotó en una Relación de las calidades de los españoles, donde equipara el [Lazarillo] con el Guzmán y el Quijote, que: "Libros de cavallería y de entretenimiento ay muchíssimos y los más dellos impertinentes, aunque ay algunos muy lindos, o a lo menos bien reçibidos, y son: La Celestina, Lazarillo de Tormes, Primera parte del Pícaro y D. Quixote de la Mancha". [...] Y Quevedo, por su lado, en la España defendida (1609), capítulo IV (De la lengua propia de España, de la lengua antigua y de la de ahora. La razón de su gramática, su propiedad, copia y dulzura), preguntaba, aprovechando la obrita para hacer la Laus Hispaniae y sobre todo de su lengua: "¿Qué tenéis que comparar con la tragedia ejemplar de Celestina y con Lazarillo? ¿Dónde hay aquella propiedad, gracia y dulzura? ¿Qué nación no los ha hecho tratables a su idioma como ha podido, hasta los turcos y moros?"» (pp. 61-62).

10. Aunque no se trate de un texto genuinamente picaresco, sino de una novela morisca en el interior de otra picaresca, Cavillac (2010, p. 64) observó que el amor que Ozmín sentía por Daraja («De modo idolatraba en ella que, si se le permitiera, en altares pusiera sus estatuas. En ella ocupaba su memoria, por ella desvelaba sus sentimientos, de ella era su voluntad») «connota la amatoria profesión de fe enunciada por Calixto ("Melibeo soy, y a Melibea adoro, y en Melibea creo"), en La Celestina, obra cuya presencia está latente en el Guzmán». Sobre las fuentes y modelos de Alemán continúa siendo fundamental el libro de Cros (1967). No deja de resultar divertido que al final de una traducción inglesa en dos volúmenes del Guzmán (The Life of Guzmán d'Alfarache or The Spanish Rogue, Londres, 1707) nos topemos con The Spanish Bawd, o sea, con La Celestina, atribuida por error al contador sevillano: «Whoever will give themselves the Trouble to read over Mateo Aleman's Celebrated Dramatick Poem, call'd Celestina, or, The Spanish Bawd» (Batlle, 2014).

11. Ver Snow, 2013, pp. 151-154. Uno de los ensayos más sagaces al respecto es el de Rodríguez (2001), quien en los capítulos iniciales de La literatura del pobre hermanó (o ahijó) a Lázaro de Tormes con la Celestina

12. Ver Barrio Olano, 2016 
collar de hechicera» al final de la trama, dando un paso más -el definitivo- hacia el modelo de la prostituta de Rojas.

A lo largo de mi análisis del filme subrayaré otros rasgos que prueban su filiación con La Celestina: verbigracia, las criadas de La tía fingida asumen un papel más cercano al de Elicia y Areúsa, siervas de la alcahueta, que al de las frívolas y desdibujadas dueñas de la obra de Cervantes ${ }^{13}$. Asimismo, Márquez Villanueva apuntó que los estudiantes de La tía fingida, al conocer a doña Claudia, «derribaron sus bonetes con un extraordinario modo de crianza y respeto, mezclado con afición» (Cervantes, La tía fingida, p. 629); mientras que Celestina recordaba con nostalgia aquellos tiempos en los que «veía derrocar bonetes en [su] honor, como si [ella] fuera una duquesa» (Rojas, La Celestina, p. 237). Luego Cervantes -si es que estamos hablando de Cervantes- no dudó al echar mano de uno de sus libros de cabecera ${ }^{14}$.

Eso sí, la fidelidad al género no era un asunto que obsesionara a los guionistas de Televisión Española. La etiqueta de «pícara» les valía para cualquier mujer que usara sus encantos y artes para salirse con la suya. O en palabras de Salas Barbadillo (2008, p. 148), «amigas importantes, [...] mujeres de negocios que saben con habilidad acomodar gustos ajenos mejor que si fueran propios». De acuerdo con este criterio, la novela del manuscrito Porras, protagonizada por dos rameras disfrazadas de nobles, se ajustaba a la perfección al resto de los capítulos de la serie ${ }^{15}$.

Y tampoco pasemos por alto el contexto en que se filmó: «la triste "apertura" del Destape», como la bautizara Caparrós Lera (1976, p. 67). El paulatino aggiornamento de España durante la dictablanda y la derogación de la censura en 1977 darían paso a un cine de esparcimiento, desprejuiciado, y que, sin excesivas pretensiones, ansiaba mostrar todo lo prohibido por el Régimen, especialmente si tenía que ver con el sexo ${ }^{16}$.

13. Téngase muy en cuenta el estreno en 1969 de la adaptación de La Celestina por parte de César Fernández Ardavín: un filme que Antonio del Real y Juan José Alonso Millán probablemente vieron y consideraron antes de pergeñar su capítulo para Las pícaras

14. A este homenaje se suma la ironía de que en Salamanca «university regulations at the time prohibited their students to take off their birettas in order to salute prostitutes in public» (Hsu, 2005, p. 225). Sí que era un gesto obligado, en cambio, delante de señoras respetables. De modo que, por tratarse aquí de unas completas desconocidas, la cortesía de los estudiantes debería interpretarse como un acto de reverencia y a la vez de rebeldía.

15. Extraña, sin embargo, que casi no haya desnudos en La tía fingida/TV, en la medida en que la Claudia de la novela repara hasta tres veces el virgo de Estefanía y sí que abundarían en los otros cinco episodios de Las pícaras: los varios cineastas «muestran a Norma Duval (Lozana), Amparo Muñoz (Rufina), Victoria Vera (Elena) o Ana Obregón (Justina), enjabonándose en una tina. La lógica de esta recurrente escena es estética y no argumental» (España, 2017, p. 389). Sobre las relaciones adulterinas en la novela corta, siempre dentro de los límites impuestos por la moral católica y la censura, ver Rey Hazas (1990, p. 272). 16. Recordemos que durante el franquismo la censura hizo gala de distintos niveles de severidad. Por lo que afecta a la pantalla, a principios de los años sesenta comenzó a relajarse. Ya en 1962 se pudo ver el primer biquini de la historia del cine español en La bahía de Palma (Juan Bosch). Poco a poco, los exponentes del Nuevo Cine y el reclamo de una audiencia cada vez más acostumbrada a la tónica hollywoodiense - con la que los censores se mostraban bastante más transigentes - irán forzando un 
La mayoría de los profesionales que salen en los créditos de La tía fingida fueron altamente representativos de esta nueva ola ${ }^{17}$. Así, el productor José Frade ha pasado a nuestra historia reciente como uno de los padrinos del Destape. Le debemos, sin ir más lejos, el primer desnudo frontal de la Democracia, en el haber de María José Cantudo (La trastienda, Jorge Grau, 1975). El guion de La tía fingida lo firmó Juan José Alonso Millán, dramaturgo de éxito (El cianuro, ¿solo o con leche?, 1963; Juegos de sociedad, 1970; Los misterios de la carne, 1984) que también ejerció como libretista de impagables desatinos: Dormir y ligar: todo es empezar (Mariano Ozores, 1974), Las delicias de los verdes años (Antonio Mercero, 1976), Historia de S (Paco Lara Polop, 1979), El Cid cabreador (Angelino Fons, 1983), Juana la loca... de vez en cuando (José Ramón Larraz, 1983) y, sobre todo, No desearás al vecino del quinto (Ramón Fernández, 1970), durante casi tres décadas el mayor taquillazo del entonces raquítico -en términos monetarios - cine patrio, amén de fundador del landismo ${ }^{18}$.

La banda sonora de Eduardo («Teddy») Bautista, el líder del grupo Los Canarios, apuntaló tan bizarra estética. Aplaudido por aquellos días, contribuyó de forma decisiva al triunfo de la versión española de la ópera rock Jesucristo Superstar (1975), estrenada en nuestro solar por Camilo Sesto. Entre sus coqueteos con el Siglo de

lento aperturismo. Por fin, la muerte de caudillo en 1975 daría inicio al Destape. Ver Joric (2015). La tele tampoco escapó a las tijeras de Franco. Muy al contrario, el nuevo medio se convirtió en un instrumento del Régimen, que pronto advirtió el potencial de «la caja tonta» para calar en los hogares: «en el terreno mismo de la ficción española se mantenía la emisión de obras de encargo con claras funciones propagandísticas» (Bustamante, 2006, s. p.). Dentro del cervantismo, la adaptación de Rinconete y Cortadillo que preparaba Basilio Martín Patino para la serie Cuentos y Leyendas fue interrumpida en plena grabación porque Manuel Fraga, ministro de Información y Turismo, había escuchado que el set de rodaje era «un nido de rojos» (Fernández Fernández, 2014, p. 37). Las pícaras se separan de ese amenazante contexto, ya que en 1983 el Destape flaqueaba a causa de la sobrecarga de desnudos que habían tomado la cartelera a partir de 1976. Además, la legalización de la pornografía en 1982, que daría al traste con la etiqueta de «cine S» - susceptible de herir ciertas sensibilidades-, hizo que amainara la demanda de carne en las películas convencionales.

17. De hecho, los culpables de Las pícaras coincidieron en multitud de producciones de la época. Mauricio, mon amour (Juan Bosch, 1976), escrita por Alonso Millán, fue protagonizada por Amparo Muñoz; e Historia de S (1979), del mismo guionista, la dirigió Paco Lara Polop (luego responsable del capítulo II de la serie de TVE: La garduña de Sevilla). Ambos volverían a verse las caras en La masajista vocacional (1981), de nuevo producida por Frade. La primera película de Antonio del Real llevó por título El poderoso influjo de la luna (1981) y contó con la presencia de Cristina Marsillach (la viuda valenciana de la tercera entrega de Las pícaras). Ya en su segundo largo, Buscando a Perico (1981), participaron tanto el omnipresente Frade como Eduardo «Teddy» Bautista (quien, además de componer la música, tuvo un pequeño papel). Por último, en El Cid cabreador (1983), Frade, Alonso Millán y Fons (el director de La hija de Celestina) trabajaron codo con codo; y en Café, coca y puro (1984) Del Real volvió a contratar a Fiorella Faltoyano (la Grijalba de La tía fingida).

18. Auspiciado por Frade, se llamó «landismo» al género formado por aquellas películas que «representaba[n] al español como un reprimido ligón de turno que, en un escenario que tenía generalmente como fondo las míticas ciudades del boom turístico, deambulaba entre la soltería y el disfrute de su condición de "rodríguez de fin de semana", afanándose en la caza de la extranjera, más accesible sexualmente que la mujer española» (Suárez, 2016, p. 613). Con frecuencia estaban protagonizadas por el actor Alfredo Landa. 
Oro, cabría rescatar su disco de rock progresivo Ciclos (1974), una suerte de reinterpretación electrónica de Las cuatro estaciones de Vivaldi9 ${ }^{9}$.

Detrás de la cámara se colocó el ya mencionado Antonio del Real. Probablemente, Frade le ofrecería este trabajo luego de su feliz colaboración en Buscando a Perico (1981), rodada por el jienense dos años antes que Las pícaras. Por último, Lola Forner fue la cara que dio sentido a la parafernalia exhibicionista. Coronada Miss Madrid en 1979 y finalista tanto en Miss Mundo como en Miss Europa $(1980)^{20}$, su carrera televisiva despegaría justo en 1983, pues La tía fingida supuso su debut en la pequeña pantalla ${ }^{21}$. Otro de los rostros más celebrados de aquel ciclo fue el de Fiorella Faltoyano. Musa de la transición gracias al díptico de José Luis Garci (Asignatura pendiente, 1977; y Solos en la madrugada, 1978), se puso en la piel de Grijalba, una de las criadas de don Félix, que en el mediometraje de Antonio del Real cobra incluso más protagonismo que Esperanza.

En tales condiciones, el argumento de esta novela les vino de perlas a los creadores de Las pícaras para divulgar la España de los Austrias mayores. Lo resumo de forma sucinta: Salamanca, 1575. Dos estudiantes manchegos, más amigos del «rodancho» que de consumirse sobre los libros, se extrañan de la apertura de una celosía en la fachada de una casa que, hasta entonces, solo se había usado como serrallo. Sus nuevas inquilinas, de aspecto principal, no tardarán en volver de su paseo. Enseguida, ambos se enamoran de la más joven y sabrán por un vecino que la que los trae locos atiende por Esperanza y es sobrina de la otra: doña Claudia de Astudillo y Quiñones. Esa misma noche se presentan bajo su balcón para «darle una música» (Cervantes, La tía fingida, p. 629), pero una de sus dueñas los despide con cajas destempladas. Hundidos por el fracaso, deciden acudir a don Félix, hacendado caballero y curtidísimo galán, para que los ayude en la conquista de la muchacha. A tal efecto, el noble se concierta con Grijalba, una de las criadas de la protagonista, quien, a cambio de un pequeño soborno, lo meterá en la casa, ocultándolo detrás de la cama de la sobrina. Su escondite le permitirá escuchar una conversación en la que se nos revela la verdad: a doña Claudia y Esperanza no las une otro parentesco que el del prostíbulo.

Un estornudo delata la presencia de don Félix y doña Claudia se dispone a hacerle frente. El corregidor, que había salido de ronda, oye aquel jaleo e irrumpe en la mansión sin dudarlo. Una vez resuelto el caso, encarcela a las dos impostoras.

19. Ver la tesis de Delis Gómez, 2016.

20. Muchas misses supieron jugar la baza del cine de destape, el cual les permitía mantenerse en el estrellato. No en balde, aquellos concursos de belleza generaron un sustancioso catálogo de sex symbols en potencia. También Norma Duval, joven protagonista de La lozana andaluza y luego reputadísima vedette, participó en el certamen de «Miss España 1973» como representante de Madrid. Se trata de la misma edición que ganaría la malagueña Amparo Muñoz, que -luego de coronarse Miss Universo en 1974- prestó su rostro y maneras a la Rufina de La Garduña de Sevilla. Ver Aguilar, 2012.

21. Lola Forner posee una fructífera carrera como actriz de televisión. Su currículum lo adornan series como Los desastres de la guerra (1983), Amor de papel (1993, telenovela venezolana); La forja de un rebelde (1990) de Mario Camus, Calle nueva (1998), La familia... 30 años después (1999), El secreto (2001) y En nombre del amor (2008) (<https://www.imdb.com/name/nm0286499/>, consultado el 21/04/2020) 
Pero los bachilleres -anónimos en toda ocasión- urden un plan para liberarlas y logran que Esperanza eluda su castigo. Finalmente, uno de ellos pedirá su mano para por fin gozarla. Y ella le da el sí de inmediato, feliz de dejar atrás sus días como cortesana. Por último, Claudia será condenada «a cuatrocientos azotes y a estar en una escalera con una jaula y coroza en medio de la plaza» (Cervantes, La tía fingida, p. 649) 22

Antes de sondear el capítulo de Antonio del Real, no estará de más volver sobre la discutida inmoralidad de la obra, uno de los clavos a los que suelen agarrarse los contrarios a la autoría cervantina. Porque, en realidad, las daifas cumplen aquí un doble destino. La vieja proxeneta dará con sus huesos en el calabozo y será ajusticiada: el símbolo del doblez y de la codicia recibe su merecido. Es verdad que a Esperanza le toca un final feliz; pero diríase que también justo, dado que desde niña se había visto condenada a otra cárcel por su falsa tía: esta vez física, y hasta sexual. Recordemos que Claudia la recogió en la puerta de una iglesia y que pronto empezaron los abusos. Es, pues, a través del matrimonio como Esperanza, «que de más bajo partido fuera contenta» (Cervantes, La tía fingida, p. 648), consigue prosperar. Entonces, La tía fingida nos regala un desenlace típico de la picaresca femenina, pues «a excepción de Elena [La hija de Celestina], las tres vidas de las pícaras [Justina, Teresa de Manzanares y Rufina -la Garduña de Sevilla-] acaban en boda, lo que no parece casual en relatos tan marcados por el galanteo, el trato sexual, la estafa amorosa e incluso el amor aparentemente sincero» (Arredondo, 1993, p. 28).

Enfocadas las claves del relato literario, vengamos ya al análisis fílmico del primer capítulo de Las pícaras, que voy a dividir en tres bloques: 1) la aventura de los estudiantes - ausente en el texto-, previa a su encuentro con Esperanza; 2) la aparición de la tía y la sobrina, que propicia el desdoblamiento de la trama; 3) fruto del anterior, examinaré, por un lado, los lances que incumben a los bachilleres y, por el otro, el que gira en torno al apuesto don Félix y a sus idas y venidas con las falsas cortesanas.

\section{DOS PÍCAROS Y UN GALÁN}

Como decía, el ambiente de La tía fingida funcionaba a las mil maravillas para una serie del corte de Las pícaras. Harina de otro costal es su trama, y más en concreto la brevedad de la misma. En la novela, toda la peripecia evoca el encuentro de los estudiantes con un par de damas, su súbito enamoramiento, la fallida ronda nocturna, la mediación de don Félix, que logra deslizarse hasta la alcoba de Esperanza, y la sorpresa de que ambas eran un fraude. De hecho, según Márquez Villanueva (1991), tanto por el descaro del tema tratado como desde el punto de vista técnico, nos hallamos ante «una novelita elemental, basada en una transparente

22. Este final se asemeja al de Méndez, otra truhana vieja y compañera de fatigas de la hija de Celestina, quien, como doña Claudia, era aparentemente «mujer muy cumplida de tocas y rosario» (Salas BarbadiIlo, La hija de Celestina, p. 97). Después de que se descubra que tanto Elena de la Paz como su amante, Montúfar, y Méndez han fingido llevar una vida devota solo para ganar dinero, la última es condenada a «cuatrocientos azotes de muerte» (Salas Barbadillo, La hija de Celestina, p. 132). 
estructura dramática» (p. 121): la del entremés, que hace de ella una «comedia embrionaria, iniciada con escena de serenata nocturna, seguida de obligados quid pro quos relativos a la historia de sobrina y tía» (p. 122). En este sentido, habría sido más fácil adaptar La tía fingida a la manera de Fernando García de la Vega cuando rodó La guardia cuidadosa y Los habladores (1965)23. No en vano, a menudo se ha leído La tía fingida a la luz de otro de los entremeses de Cervantes: El vizcaíno fingido (1615) ${ }^{24}$.

Sea como fuere, el resultado de la versión de Antonio del Real no fue un entremés, y tampoco un corto, sino un capítulo para TVE que roza la hora de metraje. De ahí también que Alonso Millán se viera obligado a dilatar la acción. Por consiguiente, el argumento de la cinta acaba por desviarse del texto del autor del Quijote. En primer lugar, la trama se desdobla, y aunque ligados a través del personaje de Esperanza, los colegiales y don Félix recorrerán sus propias sendas dramáticas. La dupla de bachilleres, que atienden por Miguel (Pep Corominas) y Juan (Carlos Santurio), abren el telefilme y nos presentan parte del mundillo universitario. Sin embargo, tanto en La tía fingida como en las dos adaptaciones de El licenciado Vidriera (Antonio Chic, 1973; Jesús Fernández Santos, 1974) Ilama poderosamente la atención que aquella Salamanca de 1575, un frenético hervidero cultural -el Brocense había publicado sus Anotaciones a la poesía de Garcilaso, fray Luis estaba a punto de salir de la cárcel tras la polémica sobre la Biblia de Vatablo, su tocayo y entonces jovencísimo Góngora, venido de su Córdoba natal, acababa de sentar reales, las rencillas entre agustinos y dominicos por hacerse con la mejores cátedras iban en aumento, el alma mater de la ciudad del Tormes y la de Alcalá iniciaron una carrera por ser la primera que tradujera Os Lusíadas de Camoens-, haya quedado reducida a telón de fondo, a una simple postal, tanto en las novelas de Cervantes (El licenciado Vidriera, La señora Cornelia, La tía fingida) como en sus varios traslados a la pantalla ${ }^{25}$. Diríase que aquellos guionistas no supieron exprimir una baza que podría haber dado pie a formidables tramas paralelas.

23. Estos dos entremeses de Cervantes, filmados como cortos de 27 y 17 minutos, respectivamente, fueron resultado de una coproducción entre España y Estados Unidos (Ancora / Encyclopaedia Británica Films). Al igual que La tía fingida, Los habladores se anunció como una obra cervantina, si bien su autoría todavía se antoja dudosa, pues se debate entre Cervantes, Lope de Vega y el más puro anonimato (ver Arellano, 2018).

24. «Otra gran relación enlaza a [estas obras] mucho más allá del pequeño guiño titular y la vecindad entre las disposiciones de novella y entremés. Las similitudes abrazan la acción, los personajes y algunas expresiones [...]: el juego de ingenio enfrenta a dos cortesanas (doña Cristina y doña Brígida) frente a dos estudiantes avispados (Solórzano y Quiñones) que quieren burlar a dos burladoras, la localización en la "casa de la ninfa" [...], el regalo de la cadena [...] a las rameras, el platero que vive "pared y medio" [...] y un pequeño comentario sobre el comportamiento amoroso de vizcaínos y genoveses [...]. Así pues, en cierto sentido, El vizcaíno fingido es el reverso de la historia de La tía fingida, en tanto que presenta la victoria de los estudiantes y el castigo tan cómico como merecido de las prostitutas» (Sáez, 2018, p. 57). Ver también Madrigal (2003).

25. Acerca de la adaptación de Fernández Santos, ver Aranda Arribas y Bonilla Cerezo (2018) 
En la escena que sirve como prólogo, Juan y Miguel pasean por un claustro durante un cambio de clase ${ }^{26}$. El primero le dice a su amigo que, si bien él piensa hacer novillos, lo mejor sería que asistiera a la clase de preceptiva literaria (01:30)27. Descubrimos así que su objetivo es librarse de Miguel para acudir a una cita con la bella Rosalina (María Elías), la cual, al salir de misa, les había dejado sobre un banco un mensaje sin destinatario. Tras una breve disputa, resuelven jugarse el encuentro a doble o nada: aquel que gaste la broma más cruel podrá verse con Rosalina, mientras que el otro deberá entretener a su dueña Sulpicia (María Elena Flores). Es entonces cuando da comienzo una carrera por la galería superior que desemboca en una plaza donde pecheros y mendigos sufrirán mil burlas y trapacerías: Juan y Miguel vuelcan carros, derriban escaleras, hacen rodar toneles, roban a un pobre que aparentaba ser ciego - quizá un guiño al tratado I del Lazarillo, donde el protagonista le robaba el vino al ciego- e incluso arrojan a una mujer dentro un pozo.

No obstante, a pesar de tener nombres -no así apellidos-, ambos colegiales carecen de desarrollo: son dos tipos, igual que en el texto cervantino. Valdría decir que uno es el «redoblamiento» del otro y sus respectivas funciones se limitan a su querencia por los placeres de la carne ${ }^{28}$. Ahora bien, sus pillerías se intensifican en el episodio de Las pícaras, brindando pistas de su vecindad con otro par de rufos del alcalaíno: Pedro del Rincón («Rinconete») y Diego Cortado («Cortadillo»). Pero no será esta la única pareja más o menos emparentada con Juan y Miguel dentro de las Ejemplares, ya que ambos participan de un mismo tipo -habitual en Cervantes- que, además, suele asomar en collera: el del bachiller diletante.

Por poner un ejemplo, en La señora Cornelia Antonio de Isunza y Juan de Gamboa -el nombre del segundo coincide con el de uno de los colegiales de La tía fingida/TV29 - huyen de las aulas de Salamanca para combatir en Flandes; pero llegarán a los Países Bajos -ironía superlativa - ya en tiempos de paz, de manera que se desvían hacia Bolonia con la excusa de... jir a la universidad!; o sea, de meterse en un ratonera muy similar a aquella de la que habían escapado ${ }^{30}$. Allí se verán envueltos en diversos lances que no tienen nada de académico.

26. Se trata del claustro del Palacio del Infantado de Guadalajara. A pesar de que el primer plano del capítulo muestra la portada plateresca de la Universidad de Salamanca y la trama se ubica en dicha ciudad, el rodaje se desarrolló, según nos informan los créditos, en Madrid, Cáceres, Guadalajara y en Marchamalo, un pueblo de esta última provincia.

27. Resulta curiosa la mención de esta asignatura y más si cabe el hecho de que uno de los muchachos se llame Miguel, en un claro guiño a Cervantes. Lo cierto es que el autor del Persiles no escribió preceptiva alguna y su poética hay que inferirla de sus obras en prosa y en verso. Según Riley (2001, p. 9), «[el complutense] hizo numerosas reflexiones sobre los problemas de la literatura, [...] [pero] nunca expuso sus ideas en forma de tratado o cosa semejante, sino que, directa o indirectamente, hizo numerosos comentarios críticos y teóricos a lo largo de sus escritos». Sin duda, leyó a los neoaristotélicos y, como demostró Shepard (1962), la Filosofía antigua poética (1596) de Pinciano.

28. Casalduero (1969) aplicó este mismo término a otras dos parejas cervantinas, en virtud de la equivalencia y reciprocidad de sus miembros: Rinconete y Cortadillo (p. 191) e Isunza y Gamboa (p. 225).

29. De aquí en adelante me referiré con esta fórmula al telefilme de Antonio del Real.

30. Ver Bonilla Cerezo, 2013, p. 24. 
Tomás de Avendaño y Diego Carriazo, protagonistas de La ilustre fregona, también saldrán de Burgos con la excusa universitaria y ambiciosos sueños picarescos, hasta que, en Toledo, dan con el Mesón del Sevillano y conocen allí a Constanza, futura mujer del primero y hermanastra del segundo. E incluso se podría sumar al grupo a los dos colegiales que toman a su servicio a Tomás Rodaja en El licenciado Vidriera, los cuales disfrutaban de los recreos que les ofrecía Salamanca mientras el sabio protagonista hundía su nariz en los libros ${ }^{31}$.

En la siguiente escena de La tía fingida/TV, Juan y Miguel sorprenden a Rosalina en un parque. Cansada de la cháchara de doña Sulpicia, la dama no presta ninguna atención a los versos de Boscán (Poesía, p. 466) que aquella, entusiasmada, recitará en bucle: «Amor es voluntad dulce y sabrosa / que todo corazón duro enternece. / El amor es el alma en toda cosa / por quien remoza el mundo y reverdece» (05:50). Cuando Rosalina ve a sus dos pretendientes, se escabulle sin que Sulpicia lo advierta y Juan ocupa su puesto.

Se muestran ahora un par de secuencias en paralelo: por un lado, Juan, para distraer a la dueña, recita un poema que Sulpicia alaba con fervor. Aunque dice haberlo escrito él, se trata en realidad -y fuera de toda lógica- de la continuación de la octava de Boscán que la carabina había leído unos segundos antes: «[...] en él todo comienza y permanece. / De este mundo y del otro la gran traza / con sus brazos Amor toda le abraza» (06:15; Boscán, Poesía, p. 466). Sulpicia, presa del arrebato lírico, intenta aprovecharse del mancebo, que se zafa de ella como puede. La escena invierte los roles típicos del cortejo, de ahí que brille por su comicidad. De hecho, esta dueña será uno de los personajes más sobreactuados e histriónicos de La tía fingida/TV. Su ridículo descaro, su torpeza y su bufonesca presencia la convierten en una figurona de manual (Fig. 3) ${ }^{32}$ :

JUAN.- ¡Ya está bien, señora! Las manos quietas o grito.

SULPICIA.- Sabed que soy virgen.

31. Si bien es verdad que no se ha aportado ninguna prueba categórica a favor de la autoría de La tía fingida, creo que no hay duda de que tanto sus estudiantes como estos otros de la colección de 1613 pertenecen a una misma familia cervantina. Ver también Grilli, 2002.

32. Sobre la comedia de figurón, ver Profeti, 1983, p. 10. La comedia y la novela eran géneros colindantes en la época: «Lo fluctuante de las fronteras dentro el terreno de las ficciones hace que entre géneros que hoy diferenciamos de modo evidente no existiese de hecho una abierta distinción. Es el caso de la novela corta y la comedia» (Talens, 1977, p. 131). Esta idea se ha convertido en moneda común entre los estudiosos. Ver al respecto Gutiérrez Hermosa, 1997, p. 168 y el clásico artículo de Morínigo, 1957. No extraña, entonces, que la adaptación de Antonio del Real adquiera tintes comediescos, más aún al conocer que García Arrieta (1814, pp. XXIX-XXX) aludió al relato del manuscrito Porras en los siguientes términos: «al leer [las novelas cervantinas], y especialmente la de La tía fingida, el lector observador no podrá menos de exclamar, lleno de admiración y de extrañeza: ¿cómo es que Cervantes no se dedicó exclusivamente al género cómico, que le era tan genial? [...] [Tenía todas las dotes:] ingenio, amenidad, agudeza, gracejo; sales y chistes los más cómicos; tacto el más fino para hallar y presentar el ridículo; destreza sin igual para pintar toda clase de caracteres y costumbres [...]. Y volviendo a La tía fingida ¿qué le falta para ser una hermosa comedia, sino dialogarla y pulir e intercalar algunas escenas preparatorias?». 
Juan.- ¡Yo no tengo la culpa!

SULPICIA.- Os esperaba a vos... (Pone su mano sobre la pierna de Juan).

JUAN.- (Le da un manotazo) iFormalidad, señora!

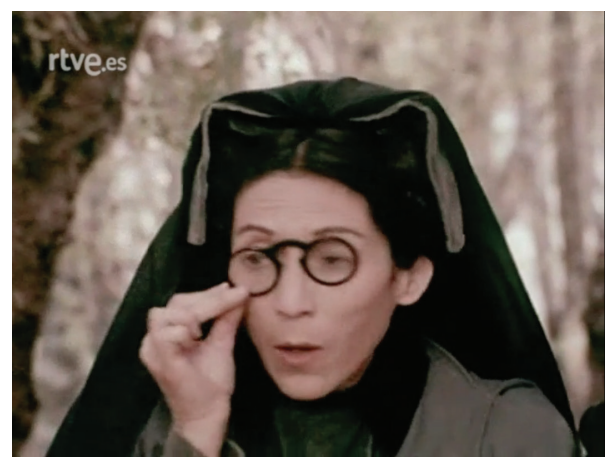

Figura 3

Entretanto, Miguel protagoniza la secuencia paralela, en la que se esfuerza por concitar la atención de una Rosalina ajena a sus favores. Descubriremos entonces que, en realidad, la hermosa mujer había citado a estos colegiales para distraer a Sulpicia mientras ella se veía a escondidas con el galán más rico de Salamanca, don Félix de Bermejo y Quiñones del Real (Emilio Gutiérrez Caba) ${ }^{33}$. Despechado el uno y acosado el otro, acaban publicando la verdad delante de Sulpicia y siguen su camino.

A continuación, los bachilleres comenzarán a husmear alrededor de la casa de doña Claudia, curiosos de la identidad de sus nuevos (y nada quiméricos) inquilinos. No destaca ninguna celosía que llame la atención de Juan y Miguel, pues en la novela se había puesto allí con un solo objetivo: «ocultar para excitar el deseo de ver y de conquistar la plaza tan guardada» (Navarro Durán, 2019, p. 18) ${ }^{34}$, toda vez que la gente de aquella casa «si no se descubría y apregonaba, no se vendía» (Cervantes, La tía fingida, p. 625). Sí repararán, por el contrario, en una persiana de esparto que desempeña la misma función.

33. Los realizadores improvisan unos apellidos para este caballero, que en la novela carecía de ellos. Desconozco de dónde pudo surgir el «Bermejo», pero «Quiñones» es uno de los nombres que se le asignaba a doña Claudia en el texto base. También «Quiñones» será el seudónimo escogido por el bachiller Trapaza de Castillo Solórzano en su etapa como estudiante en Salamanca (Castillo Solórzano, 1986, p. 69). «Del Real» acaso sea un guiño, bastante obvio, al director de este capítulo. Emilio Gutiérrez Caba ya había dado vida, por cierto, a otros dos protagonistas cervantinos en un par de series de TVE: fue el Tomás Rodaja de Jesús Fernández Santos (El licenciado Vidriera, en Los libros, 1974) y el Juan de Avendaño de Gabriel Ibáñez (La ilustre fregona, en Novela, 1978).

34. Navarro Durán (2019, p. 18), a partir de la vieja teoría de Icaza (1916, pp. 17-34), ha distinguido un claro vínculo entre la celosía de La tía fingida y la de Lucrecia en el Coloquio de las damas, incluido en los Raggionamenti (1534) de Pietro Aretino: «Y aunque yo era hermosa, aquel resguardarme de no ser vista me hacía parescer mucho más» (Xuárez, Coloquio de las damas. Diálogo, p. 22). 
Con vistas a acrecentar la intriga, los estudiantes se topan con don Félix, que los invita a merendar-como disculpa por lo ocurrido con Rosalina- para contarles la leyenda de aquella mansión:

Don FÉLIX.- Una dama principal de singular belleza quedose viuda una noche de la manera más traicionera.

JUAN.- ¿De qué murió su marido?

DON FÉLIX.- De amor.

MIGUEL.- Esas historias de romances ya no se las cree nadie.

DON FÉLIX.- Pero no fue un amor flemático y etéreo, sino apasionado y carnal, al que estaba sometido el marido bajo la tiranía de su ardiente esposa.

JUAN.- Ya no quedan mujeres así...

DoN FÉLIX.- Después de la ceremonia nupcial fueron siete días y siete noches consecutivas sin salir del dormitorio. [...] El hombre no pudo resistirlo y murió, como os he dicho, de amor (11:40).

El misterio está servido, y la lujuria ha tomado la casa. Una vivienda, por cierto, no muy distinta de otra de las descritas en las Novelas ejemplares. Como afirma Isla García (2010, p. 96), en El celoso extremeño «[todo] gira en torno a la casa, verdadera protagonista de la historia: prisión de la esposa [en el triángulo formado por Carrizales, Leonor y Loaysa, es asimismo] la caja de los misterios en La tía fingida, en la que también aparentemente se encierra [y se desploma] la virginidad». Pero lo cierto es que, en el relato que nos atañe, Cervantes no supo -o no quiso- aprovechar el potencial de dicho espacio; y tampoco Del Real le sacaría todo su partido en la versión televisiva. No sucede lo mismo en El celoso extremeño, donde, según Molho (1990, pp. 753-754),

la segunda seña que dio Carrizales de su condición celosa es la que suscita el principal resorte narrativo de la novela: la edificación de la fortaleza, al parecer inexpugnable, de la que acabará apoderándose Loaysa tras una paciente y sutil labor de penetración. La finalidad de la casa-fuerte que implanta el genio industrioso de Carrizales es asegurar la inviolabilidad de su honra. [...] La casa es ciega: se cierran todas las ventanas que dan a la calle y al jardín, y en las azoteas se levantan tapias altas que impiden mirar y ser mirado desde fuera.

En La tía fingida se da una situación análoga: será Félix el que aquí profane la hermética vivienda, tal y como Loaysa hiciera en la del indiano. Por su parte, Claudia asume el papel de Filipo Carrizales, aunque esta solo se preocupa de la honra de su sobrina y del gasto que supondría su pérdida. Sin embargo, Cervantes no nos facilitó dato alguno sobre esta casa, ni tampoco en La tía fingida/TV se le concede particular importancia, aunque a Del Real le sirva como lanzadera para subrayar que tanto el gracioso Ginés como el propio don Félix se han convertido en sendos figurones. Lo veremos luego.

Cuando el linajudo pone fin a la leyenda sobre la mansión, un criado interrumpe el ágape: entre tartamudo y bizco, funciona aquí como un «donaire» de comedia. Les informa de que sus vecinas acababan de volver y de que en ese preciso momento están abriendo las puertas. Sin pensárselo dos veces, Juan y Miguel corren 
a regalarlas. Don Félix contempla la escena desde su ventana ${ }^{35}$. Es justo ahora cuando se bifurcan las tramas. Los estudiantes, aun reconociendo la belleza superior de Esperanza, no les harán ascos a las criadas ${ }^{36}$. Don Félix, por su parte, la admira arrobado desde su domicilio y se entrega a un idilio de visu, y diríase que a primera vista. Este tipo de flechazo apela a la atracción física y se opone a la modalidad ex auditu, de corte espiritual y frecuente en la ficción idealista del siglo XVI (Ynduráin, 1983, p. 589). La química entre el galán y Esperanza será instantánea, tal como sugiere el plano-contraplano de las miradas de los futuros amantes (Figs. 4 y 5).

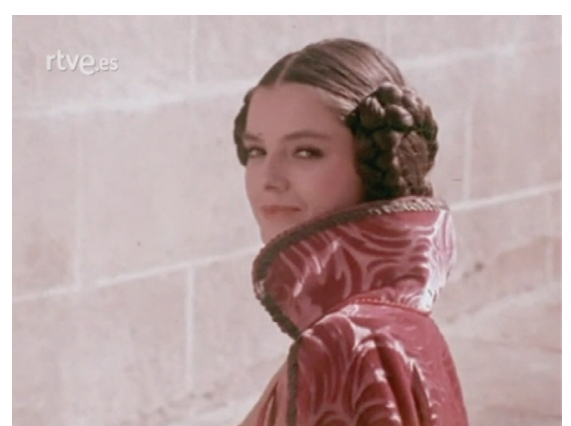

Figura 4

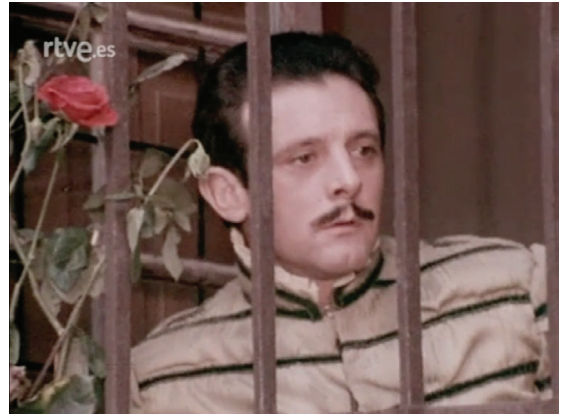

Figura 5

La prosopografía de Esperanza se narraba en la novela de forma muy plástica:

moza, al parecer, de diez y ocho años, de rostro mesurado y grave, más aguileño que redondo: los ojos negros rasgados, y al descuido adormecidos, cejas tiradas y bien compuestas, pestañas negras y encarnada la color del rostro; los cabellos plateados y crespos por artificio según se descubrían por las sienes; saya de buriel fino, ropa justa de contray o frisado, los chapines de terciopelo negro con sus claveles y rapacejos de plata bruñida, guantes olorosos y no de polvillo sino de ámbar. El ademán era grave, el mirar honesto, el paso airoso y de garza (Cervantes, La tía fingida, p. 628).

35. De nuevo, esta secuencia nos devuelve la inversión de los papeles tradicionales: en el Siglo de Oro era costumbre que, a cierta hora de la tarde, el joven pretendiente se paseara por la acera contraria a la de la dama pretendida, quien lo esperaría ya asomada a la ventana, para mostrarle sus galas. Esta práctica fue bautizada como ventanear o hacer ventana (ver Muñoz Palomares, 2003). En este caso, será el caballero, don Félix, el que se oculte tras la ventana mientras el director se recrea en el atuendo de Esperanza.

36. Icaza (1916, pp. 48-49) puso de relieve lo absurdo de que Juan y Miguel «enamora[sen] en pareja, y, como si no les fuese bastante ser ellos dos para una moza, buscan [a] un tercer galán [...]. Agréguese que esos pícaros estudiantes, que no dan muestra de estudio ni de picardía, están creyendo que se trata de una doncella honesta y que, para cautivarla, únicamente se les ha ocurrido, antes, darle aquella cencerrada maravillosa [...] en la que, también para lograrla, sin duda "quisieron apedrealle la casa, quebralle la celosía y darle una matraca o cantaleta"». No le faltaba razón al crítico mexicano, y quizá por eso Alonso Millán aprovechó la oportunidad para amortiguar el dislate, pues ya en el primer episodio se planteaba el problema que supone la presencia de una sola dama, Rosalina, para dos festejadores. En buena lógica, su objetivo no será aquí ya la codiciada Esperanza, sino sus criadas. Además, en La tía fingida/TV la «matraca» de la que hablara Icaza se verá reducida a una serenata desprovista de toda violencia. 


\section{A juicio de Hsu (2005, p. 224), en este pasaje}

the innate loveliness of the girl enhanced by skillful human efforts, acquires here an additional captivating expressiveness. Emerging not only as a feast for the eyes but also as a delight for the nose, Esperanza's beauty is a dazzling creation of nature and artistry. It is masterfully constructed on a delightful chiaroscuro of three contrastive colors (black-red-silver white).

La aparición de Esperanza (Lola Forner) (Figs. 4 y 7) se separa ligeramente del retrato cervantino. La actriz no luce aquí mechones empolvados, sino un par de rodetes; y el traje, diseñado por Gumersindo Andrés, tampoco coincide con el original. Empero, se las arregla para imprimir en la retina del espectador una imagen similar a la del texto base. Y eso que Alonso Millán dio al traste - podría haberla puesto en la boca de alguno de sus voyeurs - con «el paso de garza», un ave cargada de valores simbólicos. Así, en el emblema «Huc egit me sola fames» de las Empresas de Juan de Villava (1613, p. 109), el lema («El hambre sola me ha traído aquí») nos aclara el sentido de la pictura (Fig. 6). Porque no se ignore que fue precisamente el hambre, la extrema pobreza, la que indujo a Esperanza a seguir los pasos de Claudia:

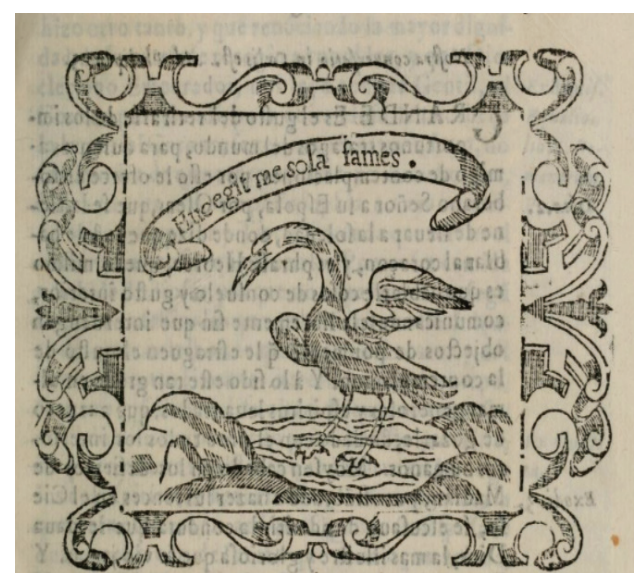

Figura 6

Pero la paleta cromática de estos planos es la misma que sugería la descriptio puellae de La tía fingida («black-red-silver white», para decirlo con Hsu). Además, el complemento de los «guantes olorosos» se depura gracias a una rosa que don Félix le tira por la ventana y que Esperanza primero huele y después arroja. Su mirada rapaz tampoco deja lugar a dudas: estamos ante una seductora.

Como antítesis, doña Claudia (Carmen de Lirio), que en el relato lucía «unas tocas blancas como la nieve, más largas que una sobrepelliz de un canónigo portugués, plegadas sobre la frente, con su ventosa y con un gran rosario al cuello de cuentas sonadoras» (Cervantes, La tía fingida, p. 625), irrumpe cubierta por un oscuro manto (Fig. 7), como si se tratara -avant la lettre- de una especie de «Ber- 
narda Alba» de la Edad de Oro. Y creo que esta afinidad no es gratuita, pues el rigor de la falsa tía, celosa guardiana de su hogar, se subraya en el telefilme como jamás lo estuvo en la novela.

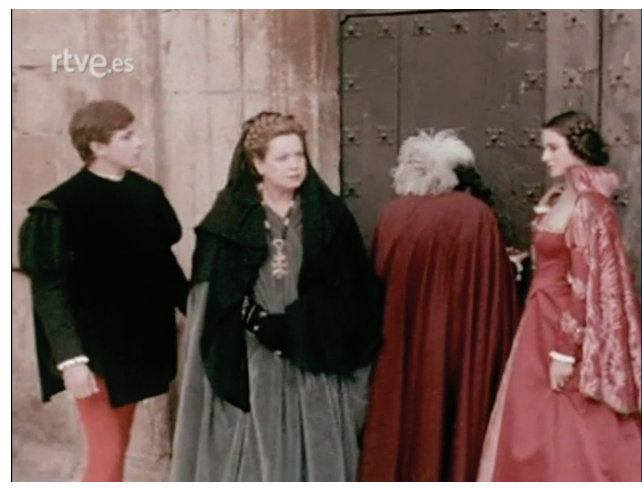

Figura 7

En el texto de Cervantes, más allá de aludir a su presencia («venían detrás dos dueñas de honor», La tía fingida, p. 629), nada se nos cuenta de las criadas. Pues bien, como ya he avanzado, Grijalba adquiere enorme relevancia dentro del guion televisivo. En cambio, su compañera nunca saldrá de las sombras. Con una diferencia: por un lado, los imperativos del destape le insuflan -y lo mismo vale para Grijalba - cierta predisposición a aceptar los lascivos martelos de los bachilleres ${ }^{37}$; por otro, aquí sí que recibirá un nombre: Estefanía (Beatriz Escudero). Conviene detenerse sobre ello, porque una de las Ejemplares con la que más se ha asociado a La tía fingida es El casamiento engañoso, cuya protagonista se llamaba, precisamente, Estefanía. Nótese que tanto la Esperanza de La tía fingida como la Estefanía del Casamiento engañoso quieren dejar atrás los lupanares, mienten acerca de su condición, «saben cómo deberán comportarse y exigen su parcela de libertad» (Isla García, 2010, p. 97). Hasta el punto de que Sáez (2018, p. 56) ha sugerido que la Estefanía del Casamiento engañoso es «la "hermana mayor" de Esperanza»; y no solo por edad: treinta años frente a los dieciocho de la sobrina de doña Claudia, sino por su experiencia. Empero, «si para Estefanía el matrimonio es el engaño, [...] el fraude de Esperanza parece ser otra cosa que acaba en casamiento solo en el último minuto, cual solución pintiparada» (Sáez, 2018, p. 57). Y tampoco a Apráiz (1906, p. 19) le pasó inadvertido que para probar este vínculo habría que reparar en que «el alférez Campuzano señala como de buen agüero, al visitar la casa de doña Estefanía, la siguiente circunstancia: "Sin que viese visiones en ella de parientes fingidos"».

Por último, el anónimo criado de las mujeres de La tía fingida responderá por Ginés (Antonio Gamero) en el episodio de Antonio del Real. La novela nos lo pintaba como «un escudero de los del tiempo del conde Fernán González, con su sayo ve-

37. Las actrices marcan su busto gracias a los estrechos corsés (15:44; 16:03), motivo que se convirtió en un estilema de Las pícaras. 
\|ludo, ya sin vello» (Cervantes, La tía fingida, pp. 627-628). Y nada más volveremos a saber de él. Su papel es muy otro - de veras capital- en el telefilme. Ataviado con una enorme pluma en el sombrero, se define enseguida como el mayor de los figurones ${ }^{38}$. Gesticula de forma amanerada y hasta flirtea con los dos estudiantes, que pronto lo tildarán de «bujarrón» $(17: 35)^{39}$. Por fin, Juan y Miguel se aprovechan de él para introducirse en la casa y formar, junto con las dos criadas, un pentágono amoroso que marca el final de la peripecia.

Si la trama de La tía fingida/TV se desdobla en dos historias -la de los estudiantes por un lado, y la de don Félix, por el otro-, la única que desfilará por ambas es Grijalba, quien primero acepta gustosa el cortejo de los estudiantes y, más tarde, negocia con doña Claudia y con don Félix, además de chantajear al caballero para llevárselo a la cama. Luego «Grijalba detenta en ocasiones más poder que cualquier otro personaje, incluidos los masculinos, trocando su poquedad en la novela por una posición en la que se codea y supera en importancia a los protagonistas» (España, 2017, p. 389).

Estudiaré a renglón seguido las dos tramas del capítulo de Las pícaras, empezando, como es natural, por la de Juan y Miguel.

\section{PICARESCA Y PICARDÍAS}

Los bachilleres no se harán de rogar y la misma noche de su feliz encuentro con Esperanza acuden a su balcón para ofrecerle una serenata junto a unos músicos a los que han pagado con viandas. Ahora bien, Alonso Millán no reparó -o tal vez hizo caso omiso - en el tipo de música que le dedicaban a la protagonista, pues no se trata de una ronda de cortejo al uso. Cervantes la describió del siguiente modo:

Llegose en esto la noche, y en la hora acomodada para la solemne fiesta, juntáronse nueve matantes de la Mancha, que sacaron cualquiera de una taza malagan por sorda que fuese, y cuatro músicos de voz y guitarra, un salterio, una arpa, una bandurria, dos cencerros, y una gaita zamorana, treinta broqueles y otras tantas cotas, todo repartido entre una grande tropa de paniaguados, o por mejor decir, pan y vinagres. Con toda esta procesión y estruendo llegaron a la calle y casa de la señora, y en entrando por ella sonaron los crueles cencerros con tal ruido, que puesto que la noche había ya pasado el filo, y aun el corte de la quietud, y todos sus vecinos y moradores de ella estaban de dos dormidas, como gusanos de seda, no fue posible dormir más sueño, ni quedó persona en toda la vecindad, que no dispertase y a las ventanas se pusiese. Sonó luego la gaita las gambetas, y acabó con el esturdión, ya debajo de la ventana de la dama (Cervantes, La tía fingida, p. 630).

38. Sobre los figurones de comedia y entremés remito a Madroñal Durán, 2007

39. Aunque el primer capítulo de Las pícaras -igual que el resto- no está falto de anacronismos léxicos (por ejemplo, Grijalba le dirá a doña Claudia, acerca del padre de don Félix, que «el día menos pensado, zás, cascará», 33:09), «bujarrón» no se cuenta entre ellos. El Diccionario de Autoridades define esta voz como «el hombre vil e infame, que comete activamente el pecado nefando». Y Quevedo satirizó a Góngora de esta guisa: «Poeta de bujarrones / y sirena de los rabos, / pues son ojos del culo / todas tus obras o rasgos» (Poeta de «iOh, qué lindicos!», s. f.). Ver sobre todo Martin, 2002. 
Como señaló Sáez (2018, p. 29), «el fin de la expedición no es tan romántico como puede parecer a priori y supera con mucho una simple serenata, pues se trata de una auténtica cencerrada (o matraca) ${ }^{40}$, un ejercicio lúdico y punitivo con larga tradición a sus espaldas». Dicha costumbre consistía en

una suerte poco homogénea de alborotos y algarabías que sometían los matrimonios grotescos al juicio de la risa, el escarnio público, estruendo y ruido. [...] Se producían alborotos y cencerradas en toda suerte de situaciones descritas e incluso en ocasiones en que los amantes no estuvieran casados, pero sus relaciones sexuales, tanto si eran estables como ocasionales, eran conocidas por todos y tenidas como escandalosas, por las razones que fueran (Mantecón Movellán, 2013, s. p.).

Nada extraña entonces que a Juan y Miguel se les ocurriera dedicar una matraca a las inquilinas de una casa que tradicionalmente había albergado una mancebía. Pero la cosa no termina ahí, puesto que la velada de estos dos mozos hibridará el estruendo socarrón con la serenata romántica. Los cencerros callan para cederle el turno al arpa, a cuyos sones la estudiantina recita el siguiente soneto:

En esta casa yace mi Esperanza,

a quien yo con el alma y cuerpo adoro;

Esperanza de vida y de tesoro,

pues no la tiene aquel que no la alcanza.

Si yo la alcanzo, tal será mi andanza,

que no envidie al francés, al indio, al moro;

por tanto, tu favor gallardo imploro,

Cupido, Dios de toda dulce holganza.

Que aunque es esta Esperanza tan pequeña,

que apenas tiene años diez y nueve,

será quien la alcanzare un gran gigante.

Crezca el incendio, añádase la leña.

¡Oh, Esperanza gentil! ¿Y quién se atreve

a no ser en serviros vigilante?» (Cervantes, La tía fingida, p. 631).

Los colegiales de Cervantes encargaron tales versos a un poeta que sin duda los compuso "como lo pudiera hacer un cardador o un peraile» (La tía fingida, p. 630). Huelga insistir en que nos hallamos ante uno de esos malos poetas que luego serían blanco del licenciado Vidriera ${ }^{41}$ y volverían a aparecer -ahora como

40. Ver Usunáriz, 2005 y Ruiz Astiz, 2012 y 2013.

41. Así los censuraría el loco licenciado: «iQué es ver a un poeta destos de la primera impresión cuando quiere decir un soneto a otros que le rodean, las salvas que les hace diciendo: "Vuesas mercedes escuchen un sonetillo que anoche a cierta ocasión hice, que, a mi parecer, aunque no vale nada, tiene un no sé qué de bonito!". Y en esto tuerce los labios, pone en arco las cejas y se rasca la faldriquera, y de entre otros mil papeles mugrientos y medio rotos, donde queda otro millar de sonetos, saca el que quiere relatar, y al fin le dice con tono melifluo y alfeñicado» (Cervantes, El licenciado Vidriera, p. 284). 
«autor de comedias»- en El coloquio de los perros ${ }^{42}$. Para el capítulo de Las pícaras, Alonso Millán tomó solo un par de endecasílabos (vv. 2 y 3) del original, pero manipulándolos en aras de la comicidad:

A quien yo con alma y cuerpo adoro,

Esperanza de vida y tesoro,

va asomar la cara con decoro.

Es mi amor más fuerte que el de un loro (20:48).

Para ser exactos, el guionista recicló el íncipit del texto base para improvisar el resto. La transformación logra el que el mal poeta -aquí Juan- resulte más evidente si cabe para el público de hoy, tal como subraya uno de los músicos (Caco Senante): «Muy fino no es el soneto» (21:13). No obstante, tampoco se respetaron los versos cervantinos, que, víctimas de la cómica hipometría, han perdido una sílaba: «Esperanza de vida y [de] tesoro, / va [a] asomar la cara con decoro». El jefe de la banda completará tan bizarra tonada acogiéndose a la misma técnica, que se traduce en un disparate:

Que no envidio al indio, al francés, al moro,

y, por tanto, tu amor gallardo imploro

a Cupido, que es dios de toda dulce holganza;

y aunque es esta esperanza tan pequeña

que apenas tiene años diez y nueve

y será quien la alcance un gran gigante.

Enseguida le toca a Juan continuar con un estribillo jocoso. Los endecasílabos «Crezca el incendio, añádase la leña. / ¡Oh, Esperanza gentil! ¿Y quién se atreve / a no serviros vigilante?» (Cervantes, La tía fingida, p. 631) se transforman así en la cinta:

Crezca el incendio, joh, Esperanza gentil!

Quien a tocaros se atreviese,

con un leño en la cabeza yo le diese (22:10).

Aunque el fruto resulta muy pedestre, no le regatearemos parte de su gracia. De ahí que Grijalba y Estefanía se asomen al balcón para oír la matraca. Y también Ginés, que piensa que la serenata es en su honor, se quita la bigotera (un adorno

42. «De lance en lance, paramos en la casa de un autor de comedias que, a lo que me acuerdo, se llamaba Angulo el Malo, de otro Angulo, no autor, sino representante, el más gracioso que entonces tuvieron y ahora tienen las comedias. Juntose toda la compañía a oír la comedia de mi amo, que ya por tal le tenía; y, a la mitad de la jornada primera, uno a uno y dos a dos, se fueron saliendo todos, excepto el autor y yo, que servíamos de oyentes. La comedia era tal que, con ser yo un asno en esto de la poesía, me pareció que la había compuesto el mismo Satanás, para total ruina y perdición del mismo poeta, que ya iba tragando saliva, viendo la soledad en que el auditorio le había dejado» (Cervantes, El coloquio de los perros, p. 615). Sobre este tipo ver Sobejano, 1973 y la tesis doctoral de Chivite Tortosa, 2008. Rodríguez-Luis (1980, p. 88) reparó además en la similitud de esta escena con aquella otra de La ilustre fregona en la que el hijo del Corregidor le dedica un soneto - que después será juzgado- a Constanza, sin conseguir que la criada acuda al reclamo. 
de aquella época, aquí con fines jocosos, Fig. 8) ${ }^{43}$ y corre en dirección a la música. Gracias a la bigotera se duplica la comicidad, pues esta servía a veces para acentuar la figura del «mal poeta». Cierto que en esta ocasión define al criado Ginés, y no a Juan, pero tampoco se ignore que Alonso Millán pudo conocer la comedia Amor, lealtad y amistad de Juan Pérez de Montalbán (incluida en el segundo tomo de sus Comedias, 1652), en la que un sujeto llamado precisamente Ginés cuenta la siguiente anécdota:

GINÉS Perdóname y no te azores, que no entendí que te daba disgusto cuando nombraba la causa de tus amores.

Quiérote contar un cuento al propósito de un hombre galán por lo gentilhombre, quizá te dará contento. Había un cierto poeta cuyos versos levantados eran muy solemnizados de todos los de la secta. $Y$ aqueste tal por costumbre tenía en toda manera el dormir con bigotera, dándole gran pesadumbre. Sucedió, pues, una fiesta levantarse de dormir, y comenzarse a vestir con su bigotera puesta

(Pérez de Montalbán, Amor, lealtad y amistad, fol. 189v).

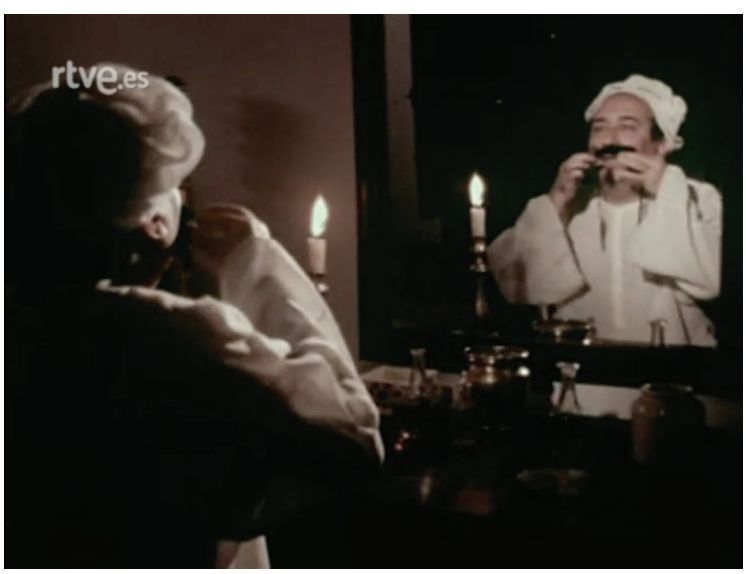

Figura 8 
La estampa cómico-sentimental llega a su fin en La tía fingida/TV con la llegada de doña Claudia para censurar la conducta de los presentes. Los aduladores cejarán en su empeño después de que los rocíen con el agua de un barreño. Se despliega entonces una interesante secuencia multifocal en la que todas las partes quedan unidas por la música del cortejo: 1) la tuna canta bajo el balcón; 2) las dueñas se asoman para escuchar sus trovas (Figs. 9 y 10); 3) Ginés despierta, se acicala y acude a un balcón distinto al de las criadas (Fig. 11); 4) don Félix, divertido, observa la escena desde su domicilio (Fig. 12); y 5) doña Claudia siente el ruido, comprueba que su sobrina sigue dormida y decide que la fiesta termine... pasada por agua (Figs. 13 y 14).

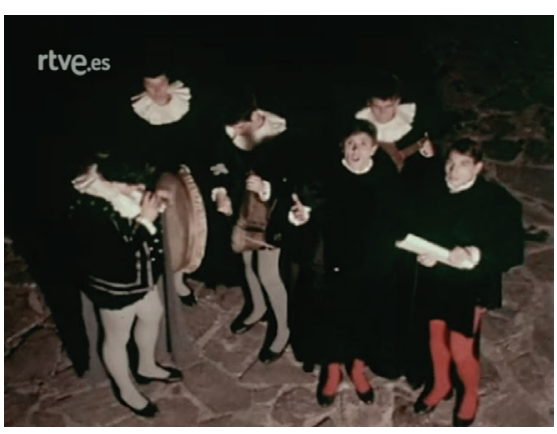

Figura 9

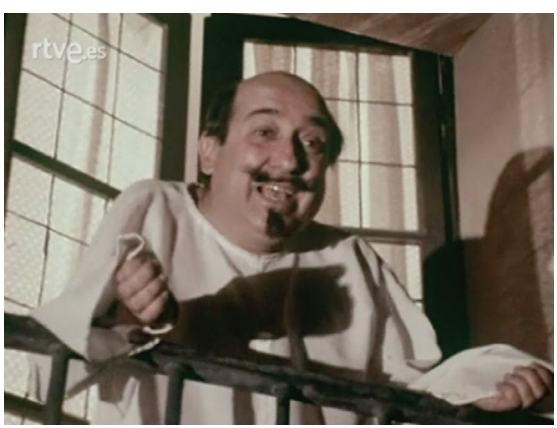

Figura 11

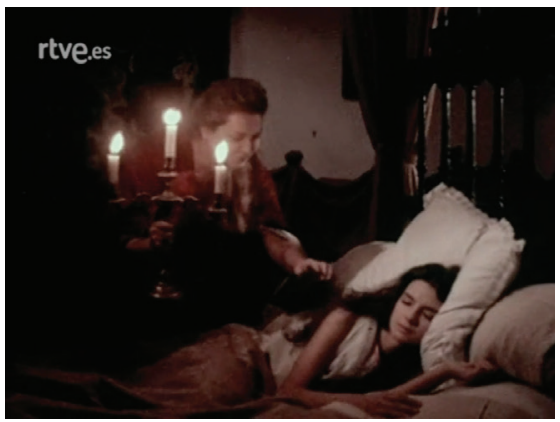

Figura 13

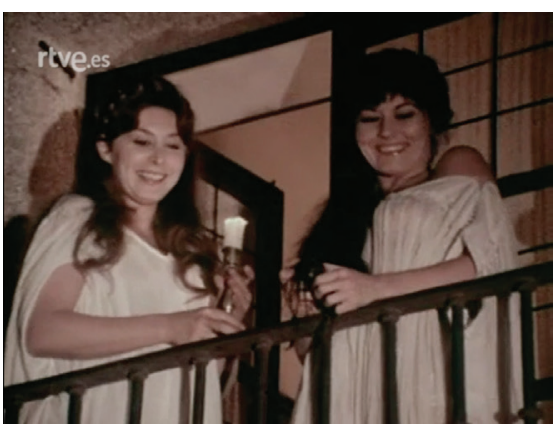

Figura 10

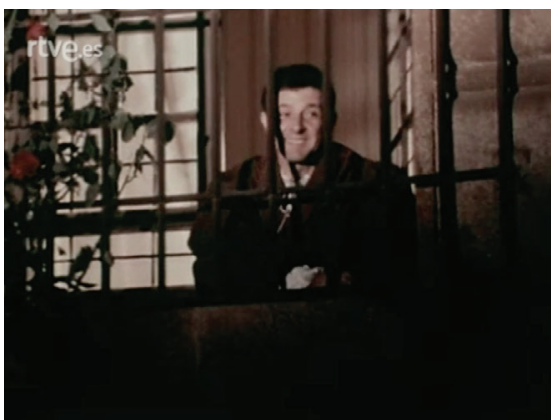

Figura 12

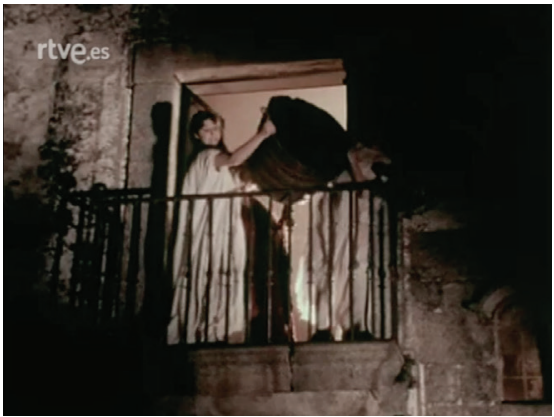

Figura 14 
La siguiente secuencia de este par de seudopícaros se localiza en una taberna (Figs. 15, 17 y 19), rodeados por unos parroquianos salidos de los cuadros de Jan Steen (En la taberna, 1660, Fig. 16) o de David Teniers el Joven (El rey bebe, 16501660, Fig. 18; Escena en la taberna, 1658, Fig. 20):

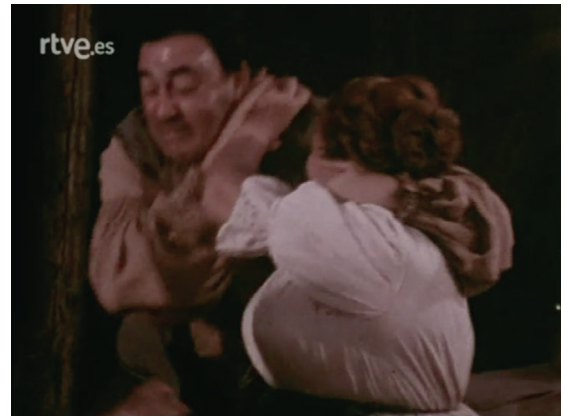

Figura 15

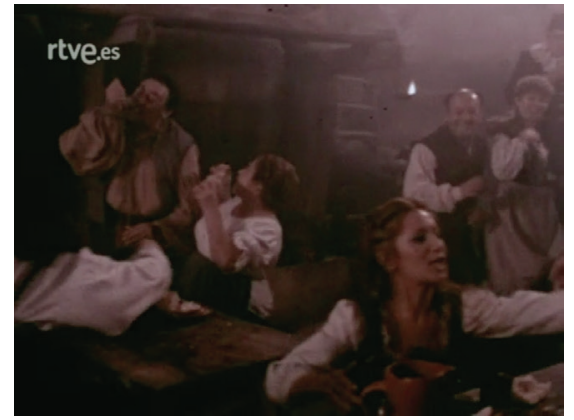

Figura 17

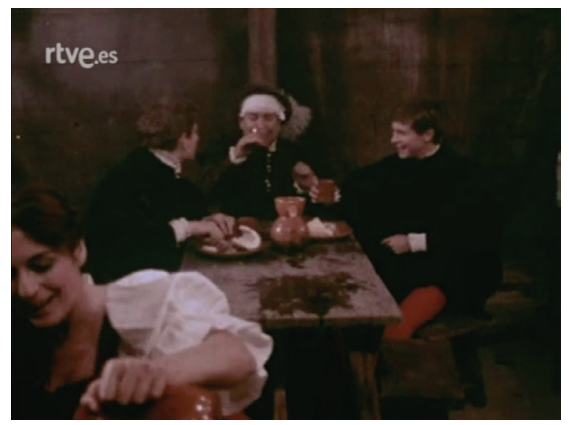

Figura 19

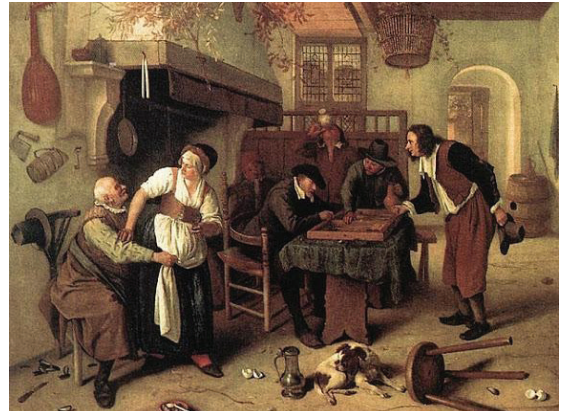

Figura 16

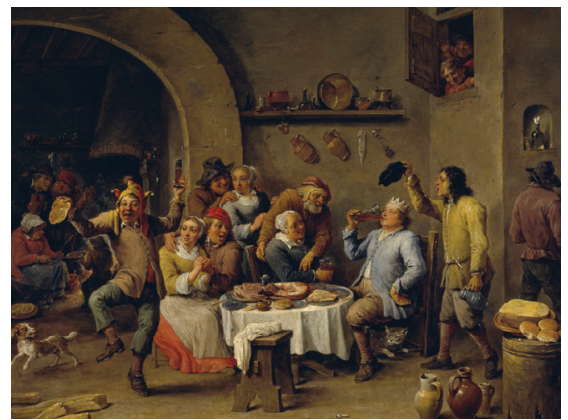

Figura 18

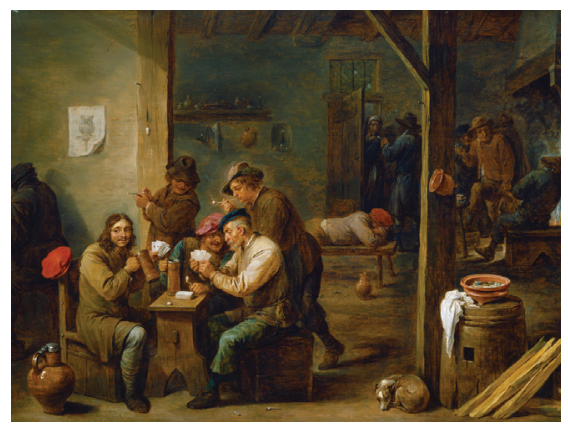

Figura 20

Se han citado allí con Ginés para convencerlo de que los cuele en la casa. Y el escudero aceptará gustoso, creyendo que los ha seducido. Esa misma noche, les tira la llave por la ventana y los espera en su cuarto, pero Juan y Miguel buscan el de Esperanza. Al final, no darán con él, sino con las criadas, que dormían plácidamente en un lecho compartido. Sin pensárselo dos veces, Juan y Miguel se despojan de 
sus ropas. Para cuando reaccionan Grijalba y Estefanía, se encuentran ya en brazos de los intrusos, un destino que no parece desagradarles. Al contrario, Grijalba exclamará con la boca pequeña: «Que nos violan!». Y Estefanía, haciéndose la coqueta, replica: «iQué más quisieras!»; a lo que su amiga responde: «Mujer, es lo que se dice...».

No tengo duda de que la escena obedece a una de esas fantasías - tan rancias como misóginas - propias del Destape. La mujer solía definirse ora como ridícula y despreciable fuente de reproches, ora como ávida hoguera de sensualidad al servicio de los hombres. Y justo este será el trato que reciban estas dos muchachas; aunque no todavía, pues doña Claudia los sorprende con las manos en la masa y expulsa a los estudiantes. Eso sí, el capítulo se despedirá con la fingida aristócrata en la cárcel y las criadas dadas a la fuga con ayuda de Juan y Miguel. Los cuatro acabarán retozando en un pajar, insaciables, rodeados de gallinas -aves del todo simbólicas, en tanto que el gallo es siempre dueño del corral y las hembras ofician como sus concubinas: del latín cubare ('yacer, acostarse')-, excitados por la música de una serenata que pone banda sonora a su desenfreno.

\section{RAMERA BUSCA ESPOSO}

Una vez cerrado el análisis de la primera trama, le toca el turno a don Félix. El caballero hará lo imposible por conquistar a Esperanza, de la que se quedó prendado nada más verla. Pero primero informa a su padre sobre ello. Nótese que el plano de don Feliciano (Carlos Mendy, Fig. 21) homenajea los señoriales retratos del último Tintoretto (Autorretrato, c. 1588, Fig. 22), mientras que el angular (Fig. 23) podría haberlo pintado un epígono de Caravaggio. Compárese, por ejemplo, con La infancia de Cristo (c. 1620), de Gerrit van Honthorst, que solía incluir el foco de luz del claroscuro -la vela, la chimenea- dentro de sus escenas (Fig. 24).

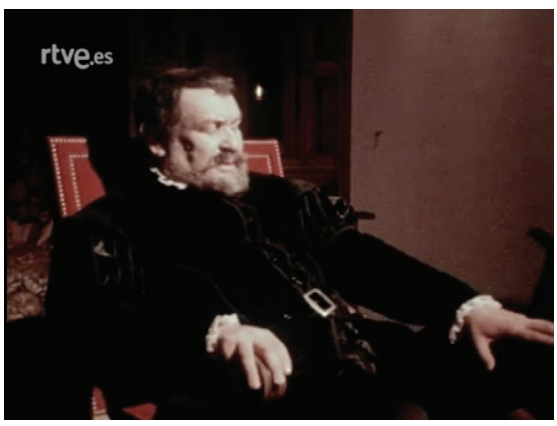

Figura 21

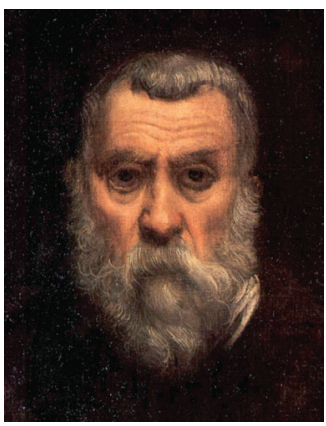

Figura 22 


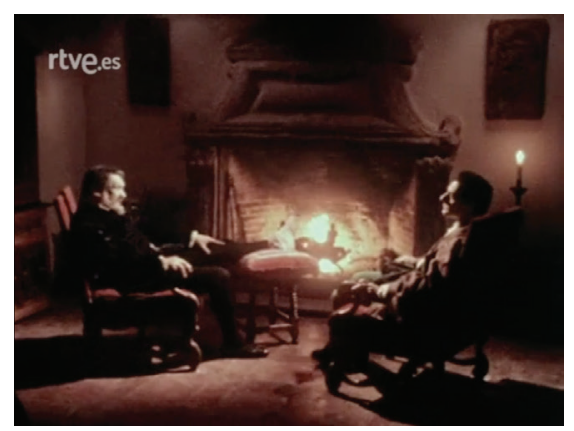

Figura 23

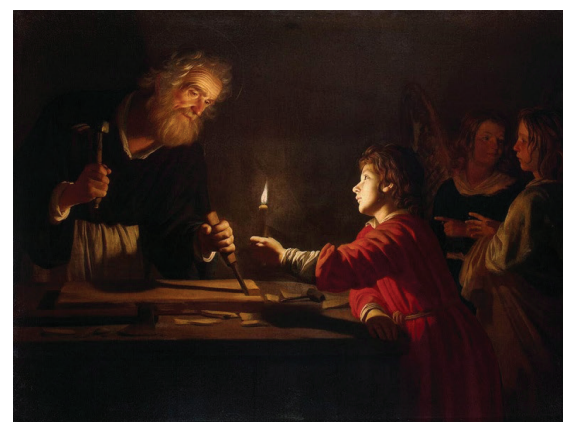

Figura 24

Don Félix acuerda con su progenitor la conveniencia de visitar a sus nuevas vecinas para presentarles sus respetos. Asimismo, le informa de su amor por Esperanza y de la pureza y correspondencia de la joven. Don Feliciano lo oye con atención y le aconseja prudencia. No obstante, a la mañana siguiente el galán aguarda a que tía y sobrina salgan a misa para hablar con Grijalba, la cual, a cambio de un anillo, le conseguirá una entrevista con doña Claudia ${ }^{44}$. Eso sí, antes le asegura que será harto difícil templar el carácter de su señora, decidida, por cierto, a enviar a su sobrina a un convento de clarisas ${ }^{45}$. A partir de aquí, don Félix se revelará como un histrión, víctima de una lectura caballeresca de la existencia que lo convierte en la mejor presa para estas pícaras. Así, mientras se tortura con la futura toma de hábitos de Esperanza, amenaza con hacer una locura.

Para tantear el terreno, el caballero las sorprende a la salida de la iglesia y recita unos solícitos versos. Si el soneto de la comparsa fue incluido en la escena oportuna, este romance - que en la novela formaba parte de aquella serenata - viene puesto ahora en labios de don Félix: «En el mar de mis enojos / tened tranquilas las aguas, / si no queréis que el deseo / dé al través con la Esperanza. / Por vos espero la vida / cuando la muerte me mata, / ya la gloria en el infierno, / y en el desamor la gracia» (29:02) ${ }^{46}$. Para infortunio del aristócrata, la sobrina desestima sus requiebros y doña Claudia lo espantará enseguida.

Pero Grijalba cumple su palabra y, mientras la alcahueta se dispone a dormir, le habla maravillas de don Félix, de manera que la vieja da su brazo a torcer y le concede una cita. Al término de su diálogo, doña Claudia se recuesta en la cama y Grijalba le alcanza un libro que resultará ser el segundo tomo de Las pícaras

44. Las escenas ubicadas en la iglesia o a la salida de misa menudean en la picaresca cortesana de Castillo Solórzano. Sin ir más lejos, La garduña de Sevilla, salía todas las mañanas «a dejarse ver en Cal de Francos o en la iglesia mayor» (Castillo Solórzano, La Garduña de Sevilla, p. 439), y será en el templo donde conocerá a Roberto, su primer amante.

45. Sobre este lugar común, ver Colón Calderón, 2001, p. 104

46. Estos versos se corresponden con los últimos ocho del romance original (Cervantes, La tía fingida, p. 632), si bien se introdujo un cambio menor en el penúltimo: «ya la gloria en el infierno» (La tía fingida/TV) frente a «y la gloria en el infierno». Dicho ajuste lo mismo pudo ser fruto de la voluntad de Alonso Millán que de una mala copia o de un desliz de Emilio Gutiérrez Caba. 
(Fig. 25), «sacado a la luz por Antonio del Real», que no es otro -como ya sabemos- que el director del capítulo que nos ocupa y figura en la portada como «abogado de esta corte e instructivo de la Real Sociedad Económica y de la Real Academia de Buenas Letras de Sevilla»:

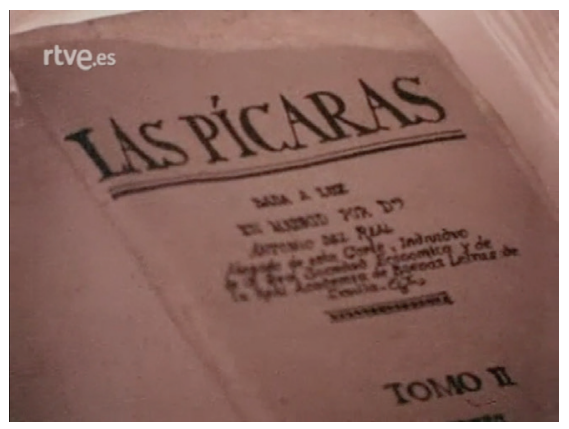

Figura 25

El chiste autoirónico y metaficcional representa un doble anacronismo que primero tiene su sal y, más tarde, su pimienta. Naturalmente, Antonio del Real, cineasta del último cuarto del siglo XX, no ha escrito ningún libro picaresco de mediados del Renacimiento; pero es que, además, la primera pícara española no es sino la ya citada Justina, cuya historia se publicó en 1605; con independencia, claro está, del guiño implícito a la serie producida por Frade para TVE.

Y tampoco se olvide que la historia de La tía fingida se desarrolla en 1575. A esas alturas el único pícaro de nuestras letras era Lázaro de Tormes, cuyas fortunas terminaron en 1559 en el Index librorum prohibitorum, del que solo saldrían, en el año 1573, gracias a la edición castigada por López de Velasco ${ }^{47}$. Más aún: no hay noticias de que las mujeres de la época, salvo que -otro acierto de TVE- también fueran pícaras, como doña Claudia, leyeran obras de este tipo, sino más bien libros de pastores. Luego esta dueña de La tía fingida/TV se recrea con Las pícaras como un libro de ficción; pero no solo, y esto es lo decisivo: a doña Claudia le sirve como un espejo no ya de príncipes (o princesas) ${ }^{48}$, sino de "pícaras con algún pícaro», género -el del «espejo de rufos»- que no llegó a cultivarse como tal49.

De vuelta al enredo amoroso, Grijalba visita de nuevo a don Félix para comunicarle las buenas nuevas, si bien ahora pide otro premio, pues el anillo no le basta. El donjuán enseguida le dará unas monedas que la criada rechaza. Grijalba -cual volcán en erupción- confiesa que lo que de veras desea es yacer con él. De esta forma, la criada atenta contra las dobles parejas de la comedia lopista que el capítulo había remedado hasta aquí. Don Félix, sabedor de su atractivo, la rechazará

47. Ver Coll-Tellechea, 2012 y, sobre todo, Ruffinatto, 2005-2006.

48. Ver Bizzarri, 2012

49. Podría ser mera casualidad, pero una de las dos primas protagonistas de El estudiante confuso (Mojiganga del gusto, 1641) de Andrés Sanz del Castillo (2019, pp. 71-104), que se desarrolla en Salamanca y en la que no escasean las trapacerías, atiende por doña Claudia. 
con delicadeza, pues su corazón le pertenece a Esperanza. Grijalba, despechada, toma el dinero a regañadientes y se marcha.

No será este último soborno, sino el buen fondo de la criada, los que conduzcan a don Félix hasta el lecho de Esperanza. El caballero acude a la entrevista con doña Claudia, que le romperá la ilusión de casarse con su sobrina. El caballero le obsequia entonces un medallón que había pertenecido a su madre, con el deseo de que no lo luzca ya ninguna otra más que Esperanza. Este detalle enlaza con la cadenilla que el caballero de la novela le daba a Claudia una vez destapado el pastel: la misma que esta rehusaba, convencida de que la (fingida) castidad de Esperanza valía mucho más ${ }^{50}$. La cortesana televisiva, por su lado, acepta de inmediato el regalo, que remite a otra célebre alhaja de nuestras letras: la cadena de oro que Calisto entregó a Celestina en pago por sus buenos servicios. Si bien se mira, la transacción es idéntica y doña Claudia una alcahueta que, ufanándose de su falsa alcurnia, estima el medallón como la primera ganancia por sus negocios de amor.

Al abandonar el salón, don Félix le confiesa a Grijalba su intención de quitarse la vida, al más puro estilo de Calixto: «Cuenta a toda Salamanca que un hombre apuñaló su corazón para acallarle eternamente» (44:00). La escena de nuevo resulta cómica por el dramatismo del galán y el absurdo forcejeo que lo sigue, hasta el punto de hacerle perder su lechuguilla. La dueña, ante tamaño desvarío, se decide a ayudarlo, pero no sin dejar bien claro que espera su galardón. Con la impudicia que siempre la caracteriza, y mientras se arrima al caballero, le susurra: «ya os daré yo alguna pista [de cómo recompensarme]» (44:46).

Don Félix se ocultará gracias a Grijalba en la habitación de Esperanza - detrás de la cama en la novelita y debajo en la adaptación televisiva-. Allí sorprenderá el diálogo entre doña Claudia y su sobrina, que en el texto cervantino precipita el desenlace ${ }^{51}$. También en el capítulo de Las pícaras descubriremos, junto al propio caballero, que ha sido el blanco de las impostoras desde el principio:

\footnotetext{
DoÑA ClaudiA.- (Risas) Está locamente enamorado de ti y ni siquiera ha oído tu vOZ.

ESPERANZA.- ¿Y tendrá tanto dinero como nos aseguraron en Madrid?

DOÑA CLAUDIA.- Mira el medallón; no deja lugar a dudas: es tan rico como tonto. Mira que creerse que yo soy tu tía...

ESPERANZA.- ¿Y ahora qué vamos a hacer?

DOÑA CLAUDIA.- Pues seguir con el juego. [...]

ESPERANZA.- Pero, si está enamorado, lo que querrá es casarse conmigo.
}

50. También en La ilustre fregona una cadena de oro adquiría cierta importancia, pues la madre de Constanza fió la mitad de una al mesonero con el que abandonó a la recién nacida. Esta habría de ser completada por el padre de la niña, tal como finalmente sucede: «al tiempo de despedirse me dio una cadena de oro que hasta agora tengo, de la cual quitó seis trozos, los cuales dijo que trairía la persona que por la niña viniese» (Cervantes, La ilustre fregona, p. 429).

51. Para Apráiz (1906, pp. 18-19), este episodio guarda afinidad con otro de Rinconete y Cortadillo: «el inimitable diálogo entre Claudia y Esperanza acerca de los modos de conservar la virginidad y atraer clientela [es equiparable a] las variadas lecciones que reciben y aun practican los ladronzuelos referentes a hurtos, cohechos y bellaquerías». 
DoÑA CLAUDIA.- Tonterías, seguiremos jugando con tu virginidad. He invertido todo mi dinero en esta operación; lo vamos a dejar sin un escudo (46:17).

En La tía fingida sobresalía un catálogo en el que Claudia clasifica a los varones de España según su rincón nativo, lo que para Márquez Villanueva (1991, p. 140) tenía que ver con que tanto los «dos estudiantes mancebos y manchegos» (Cervantes, La tía fingida, p. 625) como los músicos que los ayudan en su conquista («nueve matantes de la Mancha», p. 630) provinieran de la misma región. Ambos elementos se enraízan, a su vez, en el motivo de las nationes universitarias:

las universidades de Bolonia y París incorporaron a su gobierno el principio de nationes o comunidades que reunían a los estudiantes por su procedencia. [...] [Dichas instituciones] gozaron en sus buenos tiempos de una medida de autogobierno, con autoridades, sellos, patronos y fiestas propias [...]. Con semejante lección de «etnología amorosa» no hacía la vieja más que mostrarse más académica que nunca, en su añadidura de un nuevo capítulo a lo que desde siempre había sido un nódulo esencial de las tradiciones universitarias (Márquez Villanueva, 1991, pp. 138-142) $)^{52}$.

En el guion de Alonso Millán no queda ni rastro de este mundillo. Por otro lado, a partir de la plática entre la tía y la sobrina se subraya la firme negativa de Esperanza a la restitutio virginatis, por la que la prostituta había pasado ya en tres ocasiones:

no me dejaré más martirizar de su mano, por toda la ganancia que se me pueda ofrecer y seguir. Tres flores he dado y tantas vuesa merced ha vendido, y tres veces he pasado insufrible martirio [...]. Y si todavía está determinada que mi jardín se venda cuarta vez por entero, intacto y jamás tocado, busque otro modo más suave de cerradura para su postigo, porque la del sirgo y la ahuja, no hay que pensar que más llegue a mis carnes (Cervantes, La tía fingida, p. 642)53.

El diálogo de la adaptación no entra en tantos detalles, pero sí alude al juego de la fingida virginidad:

ESPERANZA.- Me da usted miedo. ¡Es capaz de llevarme hasta las puertas de un convento por dinero!

DOÑA CLAUDIA.- Más difícil era negociar con tu virginidad y en más de una feria te he vendido como virgen, que ya es tener imaginación...

ESPERANZA.- ¡Más difícil es hacerse pasar por señoras de calidad y que la servidumbre no sospeche! [...] ¿Y si nos fuéramos a otra ciudad? (47:09).

Cuando, ya a solas, don Félix sale de debajo de la cama y acusa a la pícara Esperanza, la mujer le responde que está enamorada de él:

52. Ver asimismo Torremocha Hernández, 2009.

53. También Celestina era una experta reparadora de virgos: «Esto de los virgos, unos hacía de vejiga y otros curaba de punto. Tenía en un tabladillo, en una cajuela pintada, unas agujas delgadas de peligeros, y hilos de seda encerados y colgadas allí raíces de hojaplasma y fuste sanguino, cebolla albarrana y cepacaballo. Hacía con esto maravillas: que, cuando vino por aquí el embajador francés, tres veces vendió por virgen una criada que tenía» (Rojas, La Celestina, p. 111). 


\section{ESPERANZA.- Os amo.}

DON FÉLIX.- ¡Embustera!

ESPERANZA.- Yo nunca os mentí. Es la primera vez que hablamos y la última [...]. Desde que os conozco pienso en modificar mi vida, ya estoy harta de esta a la que me obligan (48:04)

Y dice la verdad, porque nunca hasta ese diálogo hemos visto salir una palabra de su boca. Acaso sus miradas, entre vergonzosas, seductoras y desdeñosas, obedecieran a su amor por don Félix, pero tampoco es seguro que no interprete un papel para escapar del atolladero. No obstante, en la única conversación sincera con Claudia en La tía fingida/TV, Esperanza se muestra reticente a seguir adelante con el engaño tramado por su falsa tía.

Las lágrimas de su amada acaban por derretir a don Félix, que primero la perdonará y después yacerá con ella. Quisiera detenerme en el paralelismo entre el tropezón (50:10, Fig. 26) de don Félix rumbo a la cama de Esperanza y el de Ginés cuando entra al aposento de doña Claudia para avisarla de lo sucedido (51:00, Fig. 27). Ambos traspiés resultan muy significativos, pues perfilan la caricatura de un torpe amante, muy distinto al cervantino, cuya función en el filme se aproxima cada vez más a la de Ginés: en esta cinta comediesca, no hay caballero y gracioso, sino un caballero con trazas de gracioso y un donaire ridículo hasta la hipérbole; o sea, un figurón.

Mientras, doña Claudia, que no se fía un pelo de Grijalba, la unta para que se ponga de su lado. El trato no admite medias tintas: deberá suscribir su engañifa a cambio de una parte de las ganancias:

DoÑA CLAUDIA.- [Continuaremos] como hasta ahora. Para ti seguiremos siendo dos damas muy principales: una sobrina pura que va a ingresar en un convento y la acompaña a todas partes una tía fingida.

GRIJALBA.- Muy bien. Y sepa usted, doña Claudia, que ya he tomado mis medidas para que usted se avenga a repartir las ganancias. La tía fingida y la dueña más fingida todavía (49:33).

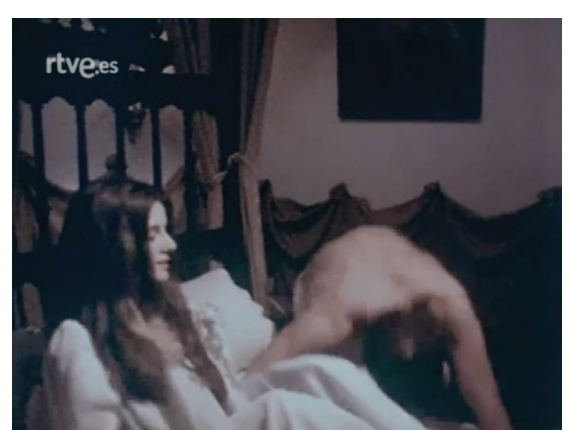

Figura 26

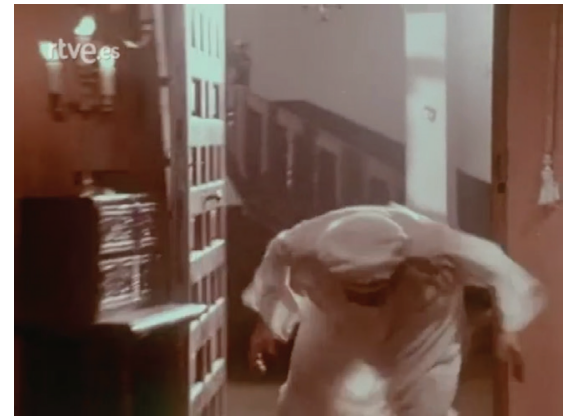

Figura 27 
Grijalba se refiere a que ella ya ha urdido su tramoya en paralelo; y, de hecho, será la única que saque algo de esta estafa. Al margen, por supuesto, de Esperanza, que accederá a la condición de dama -la «cumbre de toda buena fortuna», que diría Lázaro González Pérez- a través del matrimonio con don Félix.

Cuando la casa queda en silencio y doña Claudia se retira a dormir, Ginés distingue unos extraños sonidos que vienen del aposento de Esperanza. Mira a través de la cerradura y descubre lo que interpreta como una violación. De ahí que, sin perder un minuto, avise a su colérica ama, la cual, espada en ristre, no duda en defender la pureza (y la «cotización») de su sobrina, además de abofetearlo sin ningún motivo - otro trazo cómico-. Para librarse de cargos, Esperanza sugiere a don Félix que se ponga un traje de mujer y se haga pasar por una amiga. Aunque el galán se escandaliza en un primer momento, al final no ve otra salida; eso sí, luego de quitarse un falso bigote -recordemos la bigotera de Ginés- que deja a Esperanza patidifusa. El motivo del hombre vestido de mujer, aunque menos popular que el de la dama que se disfraza de varón, se remonta al episodio de Aquiles en Esciro, narrado por Ovidio en su Ars amandi. Y no descarto, justamente por su escasez, que Alonso Millán tuviera noticia de la novelita Amor con amor se paga, incluida por Castillo Solórzano en Los alivios de Casandra (1640): se trata de la única novela barroca por la que asoman dos caballeros en hábito de mujer: don Fernando y don Jaime Centellas ${ }^{54}$-cierto, en el libreto de La tía fingida/TV se trata de un disfrazado y de un «bujarrón»-. Así, el travestido,

conservando, como galán, su sexo genuino, pero librado de momento de cualquier compromiso social masculino, [...] llega a esbozar, en actitudes y reacciones inevitablemente nuevas, una feminidad insólita que va inventando en una constante improvisación [...]. De esta forma se elabora un modo de ser híbrido en el que [...] el disfraz femenino cumple perfectamente con su función de enmascaramiento: no oculta, sino para mejor descubrir (Canavaggio, 1978, p. 144).

Recientemente, Blanco (2019) ha estudiado este motivo en la narrativa de Castillo, porque «el tratamiento [que le da el pucelano] tiene carácter paradigmático» (p. 45) ${ }^{55}$. Aunque menos que el de Amor con amor se paga, un ejemplo lindero al de

54. En esta novela, don Vicente pretende obligar a su hermana, Gerarda, a contraer nupcias con su buen amigo don Jaime, a lo que ella se niega porque está secretamente enamorada de otro galán, don Fernando. Para burlar la incansable vigilancia de su hermano, Gerarda idea un plan que le permita encontrarse con su amado: «Entre varios discursos que hizo la dama, dio en una quimera bien extraña, y fue que don Fernando se vistiese de mujer y, de embozo, se viese con ella en la iglesia donde acudía a misa todos los días [...]. Fundó este capricho en que don Fernando era tan mozo que aún no tenía barba, era hermoso de rostro y pudo pasar plaza de mujer» (Castillo Solórzano, Amor con amor se paga, fol. 104v). Más tarde, don Jaime sospechará que la negativa de la dama a casarse con él se debe a algún amor furtivo, por lo que decidirá espiarla. El caballero repara en que tiene largas conversaciones con una joven tapada, a quien toma por su celestina. Para comprobar la identidad de esta misteriosa mujer, resuelve «el valerse de la misma traza que don Fernando, porque don Jaime era pequeño de cuerpo y de tan poca edad que el primero perfil de la barba no señalaba su bezo» (Castillo Solórzano, Amor con amor se paga, fol. 105v). Modernizo el texto.

55. Se detiene en El proteo de Madrid (Tardes entretenidas, 1625), la cornice de las Fiestas del jardín (1634) y Los amantes andaluces (1633), pero no reparó en Amor con amor se paga. 
La tía fingida/TV lo encontramos en la citada El Proteo de Madrid: el mozo Dominguillo se disfraza de ramera para gastarle una broma a un paje. Mientras camina por la estancia, su vestido se engancha en un clavo, de modo que su identidad queda al descubierto para jolgorio de los presentes. Aquí el travestismo se utiliza con fines burlescos, igual que en el capítulo de Las pícaras, donde no será un clavo, sino el zapato de Ginés el agente que desmorona el carnaval de don Félix. Las palabras de Blanco (2019, p. 51) acerca del relato de pucelano valen también para esta escena del capítulo de TVE: «los aspectos teatrales de esta secuencia narrativa son evidentes: la insistencia en aspectos semióticos como la voz o el vestido, por un lado, así como el detalle [...] del clavo que desnuda a la "dama", empleado con alguna frecuencia en la comedia barroca» 56 .

Dichos lances burlescos, junto con el añadido de los dos figurones y el cambio de la estructura narrativa de La tía fingida, acercan la reescritura de Alonso Millán más a una comedia televisada que a una novela adaptada para la televisión ${ }^{57}$. Nótese cómo al principio doña Claudia pica el anzuelo, pero cuando Ginés se tropieza con el bajo del disfraz de don Félix y desvela la identidad del aristócrata, la «embaucadora embaucada» monta en cólera y pone sobre la mesa las vergüenzas de unos y otros:

DOÑA CLAUDIA.- ¡Don Félix! ¡Os tenía por un caballero!

DON FÉLIX.- ¡Y yo por una dama principal!

DOÑA CLAUDIA.- Sois un mequetrefe del tres al cuarto que os disfrazáis de mujer.

DON FÉLIX.- Y vos la mayor alcahueta que he conocido (52:45).

Poco más se puede añadir: los dos mienten y los dos dicen la verdad. Tan solo falta que el corregidor se lleve presa a doña Claudia y a Ginés, que mira fascinado a los alguaciles: «iAy, qué hombres más fuertes!» (56:59). Esperanza y don Félix se las ingenian para huir y se personan delante de su padre, que sigue postrado en la cama. El noble le pregunta a la protagonista si es «pura», y ella no vacila en mentir: «Soy pura como la azucena y virgen desde que nací» (58:27). El señor de Bermejo y Quiñones les da entonces su bendición y se gira hacia la cámara para suspirar sus verdaderos pensamientos: «Me lo temía... Este hijo mío siempre fue un bobalicón» (59:03).

Todos engañan en este gran teatro del mundo que levantó Cervantes. Claudia finge ser una señora principal, Esperanza una recatada joven y Grijalba una criada fiel; Rosalina simula que quiere algo con uno de los estudiantes para reunirse con otro galán, y Sulpicia, su dama de compañía, vigila la honra de aquella mientras ofrece la suya a las primeras de cambio; los colegiales Juan y Miguel engatusan a Ginés; y el sirviente hace lo propio con doña Claudia, permitiéndoles la entrada en la casa; don Félix, ataviado con un bigote falso, se disfraza de dama y luego corre un velo sobre la virtud de su prometida en presencia de su padre; por fin, don Feliciano

56. Respecto a El proteo de Madrid, ver Rodríguez Mansilla, 2019.

57. La lección del dúo de Alonso Millán y Del Real puso el foco sobre este particular: don Félix, el «caballero dama», al menos por unos minutos; y Ginés, el «lindo escudero», alteran, pues, sin complejos el molde de la comedia lopista y las fórmulas del Arte nuevo. 
finge creer a Esperanza antes de dar su beneplácito para las bodas. Por tanto, la novelita del complutense y La tía fingida/TV son dos vivos reflejos del imperio de los impostores; de aquella España de Felipe II, preñada de medias verdades, en la que los dobles especulares y, con ellos, los dobles sentidos eran una moneda común $^{58}$. He aquí la razón última -y quién sabe si también la original- por la que don Félix repite a pies juntillas los movimientos de su homólogo novelesco, hasta que se vuelve loco de amor y empieza a actuar como el primero de los graciosos de esta irónica «función»; es decir, como un rico y muy inocente donjuán que acabará subiendo al altar con una linda ramera que, «mirada en partes, parecía muy bien, y en el todo, mucho mejor».

\section{BiBLIOGRAFÍA}

Aguilar, José, Las estrellas del destape y la transición: el cine español se desnuda, Madrid, T\&B, 2012.

Apráiz, Julián, Juicio de "La tía fingida». Copia de tres ediciones raras y edición crítica de esta novela, Madrid, RAE, 1906.

Aranda Arribas, Victoria, y Bonilla Cerezo, Rafael, «El licenciado Vidriera visto por Fernández Santos: un palimpsesto cervantino», Piedras lunares, 2, 2018, pp. 159-213.

Arellano, Ignacio, «El entremés de Los habladores, atribuido a Cervantes», Anales cervantinos, 50, 2018, pp. 299-323.

Arredondo, María Soledad, «Pícaras. Mujeres de mal vivir en la narrativa del Siglo de Oro», Dicenda. Cuadernos de Filología Hispánica, 11, 1993, pp. 11-33.

Aylward, Edward T., Cervantes: Pioneer and Plagiarist, Londres, Támesis, 1982.

Aylward, Edward T., «Aylward Replys to Stagg», Cervantes: Bulletin of the Cervantes Society of America, 14.1, 1994, pp. 109-116.

Barrio Olano, José Ignacio, «La Celestina y el Lazarillo en El manuscrito de piedra y El manuscrito de nieve, de Luis García Jambrina», Revista de Humanidades, 28, 2016, pp. 11-22.

Batlle, Lluís, «La traducció anglesa de La Celestina que passa a València», 09/12/2014, Institut Nova Historia. Disponible en línea: <https://www.inh. cat/articles/La-traduccio-anglesa-de-La-Celestina-que-passa-a-Valencia> (consultado el 27/04/2020).

Bernis, Carmen, El traje y los tipos sociales en el «Quijote», Madrid, El Viso, 2001.

Bizzarri, Hugo O., «Sermones y espejos de príncipes castellanos», Anuario de estudios medievales, 42.1, 2012, pp. 163-181. 
Bonilla, Adolfo, «Introducción» a La tía fingida, Madrid, Archivo de Investigaciones históricas, I, tomo II, núms. 1-2, 1911, pp. 5-17.

Bonilla Cerezo, Rafael, «Un novelista en el ducado de La señora Cornelia», Ínsula. Revista de Letras y Ciencias Humanas, 799-800, 2013, pp. 23-27.

Boscán, Juan, Poesía, ed. Pedro Ruiz Pérez, Madrid, Akal, 1999.

Bustamante, Enrique, Historia de la Radio y la Televisión en España. Una asignatura de la Democracia, Madrid, Gedisa, 2015.

Canavaggio, Jean, «Los disfrazados de mujer en la comedia», en La mujer en el teatro y la novela del siglo XVII, ed. Yves-René Fonquerne, Toulouse, CNRS, 1978, pp. 132-152.

Caparrós Lera, José María, Historia crítica del cine español, Madrid, Magisterio Español, 1976.

Casalduero, Joaquín, Sentido y forma de las «Novelas ejemplares», Madrid, Gredos, 1969.

Castillo Solórzano, Alonso, Los alivios de Casandra, Barcelona, Jaime Romeu, 1640.

Castillo Solórzano, Alonso, Aventuras del bachiller Trapaza, ed. Jacques Joset, Madrid, Cátedra, 1986.

Castillo Solórzano, Alonso, Picaresca femenina de Alonso de Castillo Solórzano: "Teresa de Manzanares» y «La garduña de Sevilla», ed. Fernando Rodríguez Mansilla, Madrid / Frankfurt am Main, Iberoamericana / Vervuert, 2012.

Castro, Adolfo de, «Un enigma literario», La España moderna, 4, abril de 1889, pp. 157-186.

Cavillac, Michel, Guzmán de Alfarache y la novela moderna, Madrid, Casa de Velázquez, 2010.

Cervantes Saavedra, Miguel de, Novelas ejemplares, ed. Jorge García López, Madrid, Real Academia Española, 2013.

Cervantes Saavedra, Miguel de, La tía fingida, ed. Adrián J. Sáez, Madrid, Cátedra, 2018.

Chivite Tortosa, Eduardo, La sátira contra los malos poetas (1554-1610): textos y estudio [tesis doctoral], Córdoba, Universidad de Córdoba, 2008.

Coll-Tellechea, Reyes, «Historia literaria, humanismo y sociedad. Juan López de Velasco: perfil de un censor político», en Rumbos del hispanismo en el umbral del cincuentenario de la AlH, coord. Patrizia Botta, Roma, Bagatto, 2012, vol. 3, pp. 24-31.

Colón Calderón, Isabel, La novela corta en el siglo XVII, Madrid, Laberinto, 2001. 
Criado de Val, Manuel, «Análisis verbal del estilo. Índices verbales de Cervantes, de Avellaneda y del autor de La tía fingida», Revista de Filología Española, Anejo LVII, 1953.

Cros, Edmond, Contribution à l'étude des sources de «Guzmán de Alfarache», Montpellier, Faculté des Lettres, 1967.

Delis Gómez, Guillermo, Rock progresivo en España como contracultura en los años del tardofranquismo: «Canarios» y «Ciclos» [tesis doctoral], Madrid, Universidad Complutense de Madrid, 2016.

Demicheli, Tulio, «Francisco Rico certifica que Latía fingida es una obra original de Cervantes másalládesuatribución»,ABC,22/11/2005. Disponibleen línea:<https:// www.abc.es/cultura/libros/abci-francisco-rico-certifica-fingida-obra-original-cervantes-mas-alla-atribucion-200511220300-712472732704_noticia. html> (consultado el 24/04/2020).

España, Manuel, «La adaptación de la novela corta La tía fingida en la serie televisiva Las pícaras (1983)», Creneida, 5, 2017, pp. 372-399.

Fernández Fernández, Luis Miguel, Escritores y televisión durante el Franquismo (1956-1975), Salamanca, Ediciones Universitarias de Salamanca, 2014.

Foulché-Delbosc, Raymond, «Étude sur La tía fingida», Revue Hispanique, VI, 1899.

Gallardo, Bartolomé José, El criticón. Papel volante de Literatura y Bellas Artes, Madrid, I. Sancha, 1835.

García Arrieta, Agustín, El espíritu de Miguel de Cervantes y Saavedra o La filosofía de este grande ingenio, Madrid, Viuda de Vallín, 1814.

García López, Jorge, Cervantes: la figura en el tapiz. Itinerario personal y vivencia intelectual, Barcelona, Pasado y presente, 2015.

Gherardi, Flavia, «Un cuerpo parecemos y una vida»: doppie identità nella narrativa spagnola del Secolo d'oro, Pisa, ETS, 2007.

Grilli, Giuseppe, «Estudiantes ocultos y estudiantes al descubierto en las Novelas ejemplares», en Actas del X Coloquio de la Asociación de Cervantistas, ed. Alicia Villar Lecumberri, Palma de Mallorca, Universitat de les Illes Balears, 2002, pp. 187-196.

Gutiérrez Hermosa, Luisa María, «La constitución de un "arte nuevo de hacer novelas": apuntes a una teoría de la novela corta», Exemplaria. Revista Internacional de Literatura Comparada, I, 1997, pp. 157-177.

Góngora, Luis de, Romances, I, ed. Antonio Carreira, Barcelona, Quaderns Crema, 1998.

Hsu, Carmen, «"La fuerza de la hermosura": The Courtesan Character in La tía fingida», en Cervantes y su mundo III, ed. Robert Lauer y Kurt Reicherbenger, Kassel, Reihenberger, 2005, pp. 223-240. 
Icaza, Francisco de, De cómo y por qué «La tía fingida» no es de Cervantes y otros estudios cervánticos, Madrid, Reales Academias Españolas de la Historia y de Bellas Artes, 1916.

Isla García, Virginia, «A vueltas con La tía fingida», en Hos ego versículos feci... Estudios de atribución y plagio, ed. Javier Blasco, Patricia Marín Cepeda y Cristina Ruiz Urbón, Madrid / Frankfurt am Main, Iberoamericana / Vervuert, 2010, pp. 75-101.

Joric, Carlos, «Las tijeras de Franco», Historia y vida, 564, 2015, pp. 62-70.

López Rubio, Lucía, El matrimonio en las «Novelas ejemplares» y el «Quijote»: la influencia del modelo histórico, social y legal de los siglos XVI y XVII, Madrid, 2016.

Lucía Megías, José Manuel, «El códice Porras (casi) recuperado (la copia del Cigarral del Carmen de La tía fingida)», Anales cervantinos, 50, 2018, pp. 334-351.

Madrigal, José Luis, «De cómo y por qué La tía fingida es de Cervantes», Artifara, 2 , 2003, s. p. Disponible en línea: <http://www.cisi.unito.it/artifara/rivista2/testi/ tiafingida.asp> (consultado el 25/04/2020).

Madroñal Durán, Abraham, «Figurones de comedia y figurones de entremés», en El figurón: texto y puesta en escena, ed. Luciano García Lorenzo, Madrid, Editorial Fundamentos, 2007, pp. 249-271.

Madroñal Durán, Abraham, Humanismo y filología en el Siglo de Oro. En torno a la obra de Bartolomé Jiménez Patón, Madrid / Frankfurt am Main, Iberoamericana / Vervuert, 2009.

Mantecón Movellán, Tomás, «Cencerradas, cultura moral campesina y disciplinamiento social en la España del Antiguo Régimen», Mundo agrario, 14, 27, 2013, s. p. Disponible en línea: <http://www.memoria.fahce.unlp.edu.ar/art_revistas/pr.5953/pr.5953.pdf> (consultado el 25/04/2020).

Martin, Adrienne L., «Góngora, poeta de bujarrones», Calíope, 8.1, 2002, pp. 141-160.

Menéndez Pelayo, Marcelino, Orígenes de la novela, primera edición [1915], Madrid, Gredos, 2008.

Molho, Maurice, «Aproximación al Celoso extremeño», Nueva Revista de Filología Hispánica, 38, 1990, pp. 743-792.

Morínigo, Marcos A., «El teatro como sustituto de la novela en el Siglo de Oro», Revista de la Universidad de Buenos Aires, 5, 1957, pp. 41-61.

Muñoz Palomares, Antonio, «El ventanear y otras prácticas de galanteo en el teatro de Mira de Amescua», en Ronda, cortejo y galanteo en el teatro español del siglo de Oro. Actas sobre el I Curso de Teoría y Práctica de Teatro, celebrado en Granada, los días 7-9 de noviembre de 2002, coord. Roberto Castilla Pérez, Granada, Universidad de Granada, 2003, pp. 277-299. 
Navarro Durán, Rosa, «Una celosía, un estornudo y una calva en La tía fingida de Cervantes», Clarín, 143, 2019, pp. 18-21.

Núñez Rivera, Valentín, «Valoraciones críticas del Lazarillo en el Siglo de Oro», en Memorias de un honrado aguador. Ámbitos de estudio en torno a la difusión del «Lazarillo de Tormes», ed. Frederick A. de Armas y Julio Vélez-Sainz, Madrid, Sial, 2017, pp. 49-67.

Pérez de Montalbán, Juan, Segundo tomo de las comedias del doctor Juan Pérez de Montalbán, Valencia, Claudio Macé, 1652.

Profeti, Maria Grazia, «Estudio preliminar» a Agustín Moreto, El lindo Don Diego, Madrid, Taurus, 1983, pp. 7-28.

Rey Hazas, Antonio, «El erotismo en la novela corta del siglo XVII», Edad de Oro, IX, 1990, pp. 271-288.

Rey Hazas, Antonio, Deslindes de la novela picaresca, Málaga, Universidad de Málaga, 2003.

Riley, Edward C., La rara invención. Estudios sobre Cervantes y su posteridad literaria, Barcelona, Crítica, 2001.

Rodríguez, Juan Carlos, La literatura del pobre, Granada, Comares, 2001.

Rodríguez López-Vázquez, Alfredo, «La novela ejemplar La tía fingida, atribuida a Cervantes», Artifara, 59-70, 13 bis, 2013, s. p. Disponible en línea: <http:// www.cervantesvirtual.com/obra/la-novela-ejemplar-la-tia-fingida-atribuidaa-cervantes-924223/> (consultado el 25/04/2020).

Rodríguez López-Vázquez, Alfredo, «Cervantes y helecho de Procusto. Notas críticas al uso de la estilometría en obras de atribución dudosa y apócrifas», eHumanista, 41, 2018, pp. 193-201.

Rodríguez-Luis, Julio, Novedad y ejemplo de las «Novelas» de Cervantes, México D.F., Porrúa, 1980.

Rodríguez Mansilla, Fernando, «Introducción» a Alonso de Castillo Solórzano, Picaresca femenina de Alonso de Castillo Solórzano: «Teresa de Manzanares» y «La garduña de Sevilla», Madrid / Frankfurt am Main, Iberoamericana / Vervuert, 2012, pp. 11-144.

Rodríguez Mansilla, Fernando, «El Proteo de Madrid: la picaresca en ciernes de Castillo Solórzano», Criticón, 136, 2019, pp. 59-72.

Rojas, Fernando de, La Celestina, ed. Dorothy S. Severin, Madrid, Cátedra, 2014.

Ruffinatto, Aldo, «Algo más sobre el Lazarillo castigado de López de Velasco», Incipit, 25-26, 2005-2006, pp. 523-536.

Ruffinatto, Aldo, «Pícar@s que no dejan huella. La muerte del picarismo en la picaresca de Castillo Solórzano», Criticón, 136, 2019, pp. 73-90. 
Ruiz Astiz, Javier, «"Haciendo algaradas y músicas": rondas nocturnas y carnavales en la Navarra moderna», Revista Internacional de Estudios Vascos, 57.1, 2012, pp. 90-126.

Ruiz Astiz, Javier, «Cencerradas y matracas en Navarra durante el Antiguo Régimen: funciones y objetivos», Hispania. Revista española de historia, 245, 2013, pp. $733-760$.

Sáez, Adrián J., «Introducción» a Miguel de Cervantes, La tía fingida, Madrid, Cátedra, 2018, pp. 13-77.

Salas Barbadillo, Alonso Jerónimo, La hija de Celestina, ed. Enrique García SantoTomás, Madrid, Cátedra, 2008.

Shepard, Sanford, El Pinciano y las teorías literarias del Siglo de Oro, Madrid, Gredos, 1962

Snow, Joseph T., «Historia crítica de la recepción de Celestina: 1499-1822», Celestinesca, 37, 2013, pp. 151-154.

Sobejano, Gonzalo, «El mal poeta de comedias en la narrativa del siglo XVII», Hispanic Review, 41, 1973, pp. 313-330.

Stagg, Geoffrey, «The Refracted Image: Porras and Cervantes», Cervantes: Bulletin of the Cervantes Society of America, 4.2, 1984, pp. 139-153.

Suárez, José Carlos, «La transición como un espacio de creación: cine, música y pintura (entre movidas anduvo el juego)», en Transiciones en el mundo contemporáneo, coord. Alberto Reig Tapias y Josep Sánchez Cervelló, Tarragona, Universitat Rovira i Virgili / UNAM, 2016, pp. 603-631.

Talens, Jenaro, La escritura como teatralidad, Valencia, Universidad de Valencia, 1977.

Torremocha Hernández, Margarita, «Nuevos enfoques en la historia de las universidades: la vida cotidiana de los universitarios en la península ibérica durante la Edad Moderna», Chronica nova. Revista de historia moderna de la Universidad de Granada, 35, 2009, pp. 193-219.

Usunáriz, Jesús M., «El lenguaje de la cencerrada: burla, violencia y control en la comunidad», en Aportaciones a la historia social del lenguaje: España, siglos XIV-XVIII, ed. Rocío García Bourrellier y Jesús M. Usunáriz, Madrid / Frankfurt am Main, Iberoamericana / Vervuert, 2005, pp. 235-260.

Villava, Juan Francisco de, Empresas espirituales y morales, Baeza, Fernando Díaz de Montoya, 1613.

Xuárez, Fernán / Aretino, Pietro, Coloquio de las damas. Diálogo, ed. Donatella Gagliardi, Roma, Salerno Editrice, 2011. 